$1-2018$

\title{
Corporate Social Responsibility and Corporate Governance
}

Cynthia A. Williams

Osgoode Hall Law School of York University, cwilliams@osgoode.yorku.ca

Source Publication:

Jeffrey Gordon and Georg Ringe (eds.) Oxford Handbook of Corporate Law and Governance (Oxford, UK: Oxford University Press) 2018

Follow this and additional works at: https://digitalcommons.osgoode.yorku.ca/scholarly_works

Part of the Law Commons

\section{Repository Citation}

Williams, Cynthia A., "Corporate Social Responsibility and Corporate Governance" (2018). Articles \& Book Chapters. 1784.

https://digitalcommons.osgoode.yorku.ca/scholarly_works/1784

This Book Chapter is brought to you for free and open access by the Faculty Scholarship at Osgoode Digital Commons. It has been accepted for inclusion in Articles \& Book Chapters by an authorized administrator of Osgoode Digital Commons. 


\title{
Corporate Social Responsibility and Corporate Governance
}

\author{
Cynthia A. Williams \\ Osler Chair in Business Law \\ Osgoode Hall Law School, York University, Toronto, Canada
}

\begin{abstract}
Chapter for OXFORD HANDBOOK OF CORPORATE LAW AND GOVERNANCE (Jeff Gordon \& Georg Ringe, eds., forthcoming)
\end{abstract}

\begin{abstract}
Corporate social responsibility has become a subject of growing importance in business and law. Today, no analysis of corporate governance systems would be complete without considering the pressures on companies to be seen as responsible corporate citizens. This chapter first provides a descriptive overview of developments in the field, including increasing voluntary and required environmental, social and governance (ESG) disclosure; and proliferating voluntary and multilateral standards for responsible corporate behavior. This chapter then reviews some of the more significant empirical evidence on the financial results of companies' implementation of corporate responsibility initiatives, including the effects of such initiatives on innovation, trust, and social welfare. It concludes with an analysis relating these developments to arguments over the objectives of the corporation and the shareholder/stakeholder debate.
\end{abstract}

\section{INTRODUCTION}

Corporate social responsibility is a topic that has been given increased attention in the last two decades in practice and in theory, both in management and law. Defined in an influential 1970's article as “the firm's considerations of, and response to, issues beyond the ... economic, technical, and legal requirements of the firm to accomplish social benefits along with the 
traditional economic gains which the firm seeks, ${ }^{1}$ the European Commission more simply defined it in 2011 as "the responsibility of enterprises for their impacts on society."2 As the Commission stated in adopting that definition, “[e]nterprises should have in place a process to integrate social, environmental, ethical, human rights and consumer concerns into their business operations and core strategy in close collaboration with their stakeholders.” 3 Thus, the emphasis has shifted from philanthropy and attention to corporate action "beyond law," to an inquiry into how a company conducts its business. Indicative of this shift, many academics and practitioners in management now refer to the topic as corporate responsibility, not corporate social responsibility, as will this author. ${ }^{4}$

What is some evidence of a developing norm of corporate responsibility? Few global companies today fail to highlight their social initiatives and performance on their websites, while over $90 \%$ of the Global 250 companies voluntarily disclose more environmental, social and governance (ESG) information than required by law. ${ }^{5}$ Voluntary, transnational standards of best social and environmental practices are proliferating in virtually every industry, many with associated certification schemes and requirements for third-party attestation or auditing. ${ }^{6}$ These voluntary initiatives are increasingly being supplemented by domestic and multilateral government actions to encourage, or in some cases require, companies to pay closer attention to

\footnotetext{
${ }^{1}$ Keith Davis, The Case For and Against Business Assumption of Social Responsibilities, 16 AM. MNGMT. J. 312, 312 (1973).

${ }^{2}$ European Commission, A Renewed European Union Strategy 2011-14 for Corporate Social Responsibility, COM (2011) 681, ๆ 3.1.

${ }^{3}$ See id.

${ }^{4}$ See Céline Gainet, Exploring the Impact of legal Systems and Financial Structures on CR, 95 J. BuS. ETHICS 195, 197 (2010)(discussing shift in nomenclature from “corporate social responsibility” to "corporate responsibility," for, among other reasons, encompassing the concept of both social and environmental responsibilities in a single term).

${ }^{5}$ See KPMG, The KPMG Survey of CR Reporting 2013, available at http://www.kpmg.com/Global/en/IssuesAndInsights/ArticlesPublications/corporateresponsibility/Documents/corporate-responsibility-reporting-survey-2013-exec-summary.pdf .

${ }^{6}$ See Margaret M. Blair, Cynthia A. Williams \& Li-Wen Lin, The New Role for Assurance Services in Global Commerce, 33 J. CORP. L. 325 (2008).
} 
the social and environmental consequences of their actions and to disclose more information about those consequences. $^{7}$

Investors as well have become more attentive in recent years to environmental and social risks in portfolio companies, and therefore more concerned with corporate responsibility. Global assets under management with sustainability screens have risen 61\% since 2012, to US\$ 21.4 trillion at the start of 2014. ${ }^{8}$ Institutions managing US\$ 45 trillion of invested capital have committed to the U.N. Environment Program’s Principles for Responsible Investment (PRI), which require investors to incorporate ESG issues into investment practices across their asset classes. ${ }^{9}$ And, as of 2015, over US\$ 92 trillion of the world's invested capital backs the Carbon Disclosure Project (CDP) 's work with 2,000 companies around the world to gather data on those companies' greenhouse gas emissions. ${ }^{10}$ These data are then provided to Bloomberg for incorporation with other ESG data that Bloomberg now sells, since 2009, to investors around the world. ${ }^{11}$ Indeed, corporate responsibility itself has become an industry, one a critical NGO noted has London “awash with PR consultants, social auditors, firms providing verification or ‘assurance’ for companies’ social and environmental reports, and bespoke investment analysts all vying for business."12

While these trends indicate that corporate responsibility has achieved some place within mainstream corporate and investor activities, that place is deeply contested, in both theory and

\footnotetext{
${ }^{7}$ See Parts II, B, 2 and III , infra.

${ }^{8}$ Global Sustainable Investment Alliance, The Global Sustainable Investment Review 2014, available at www.sustainabilityHQ.com.

${ }^{9}$ United Nations Environment Program Principles for Responsible Investment, available at http://www.unpri.org/about-pri.

${ }^{10}$ Carbon Disclosure Project, Catalyzing Business and Government Action, available at http://www.cdp.net/enUS/Pages/About-Us.aspx.

${ }^{11}$ See Table 3, infra, for a summary of the environmental and social data that Bloomberg now sells to its broker and dealer clients.

${ }^{12}$ Christian Aid, Behind the Mask: The Real Face of Corporate Social Responsibility 8 (2004).
} 
practice. Everything from the history of corporate responsibility, its importance, its effects, and its legitimacy is subject to challenge, depending on the underlying corporate governance system of a country in question, how countries arrange their social welfare provision, the relationship of the state to the market, and even the theory of the nature of the corporation one holds. In important respects corporate responsibility is both too strong and too weak: too strong an assertion of a social role for the corporation and its directors to coexist comfortably with the view of the purely economic role of the corporation within shareholder-focused corporate governance systems, and yet too weak for academics taking a stakeholder view of the corporation who are concerned with global problems they view companies as having helped to create, including climate change, environmental degradation, exploitative labor conditions and worsening economic inequality.

This chapter will proceed as follows. Part 2 will describe voluntary corporate responsibility initiatives, followed in Part 3 by some of the more significant legal developments on the topic. Part 4 will discuss empirical evidence about the financial and social effects of corporate responsibility, including interactions with corporate governance structures. Part 5 will evaluate these corporate responsibility trends, and Part 6 will conclude.

\section{VOLUNTARY CORPORATE RESPONSIBILITY INITIATIVES}

\section{A. Corporate Responsibility Reporting}

The clearest demonstration of the evolution of corporate responsibility from academic theory to mainstream business practice is in the trends with respect to corporate reporting of 
environmental, social and governance (ESG) information. ${ }^{13}$ While some jurisdictions are starting to require ESG reporting (as described below), much of this reporting is still voluntary. It can thus be interpreted as an indication of companies’ perceptions of the social expectations of business, even as companies seek to manage those expectations through their corporate responsibility reporting. ${ }^{14}$

The most comprehensive source of data on ESG reporting is that done by KPMG in the Netherlands. KPMG published its first ESG report in 1993, and its most recent in 2013. In 1993, 12\% of the top 100 companies in the OECD countries (ex. Japan) published an environmental or social report. ${ }^{15}$ By 2013, 76\% of the top 100 companies in the Americas publish a separate corporate responsibility report, as do 73\% of top 100 companies in Europe and 71\% in Asia. ${ }^{16}$ Of the largest 250 companies globally, reporting rates are $93 \% .{ }^{17}$ The Global Reporting Initiative (GRI)’s voluntary, multi-stakeholder framework for ESG reporting has emerged as the clear global benchmark: $78 \%$ of reporting companies worldwide and $82 \%$ of the Global 250 use GRI as the basis for their corporate responsibility reporting. ${ }^{18}$ Of particular note,

\footnotetext{
${ }^{13}$ For an excellent overview of the evolution of corporate responsibility as an academic theory in the management literature, see Archie V. Carroll, Corporate Social Responsibility: Evolution of a Definitional Construct, 38 Bus. \& SOC'TY 268 (1999).

${ }^{14}$ See Sara B. Feldner \& Kati T. Berg, How Corporations Manage Industry and consumer Expectations via the CR Report, 8(3) PuBliC Relations J. (2014), available at www.prsa.org/prjournal; Ronen Shamir, The DeRadicalization of Corporate Social Responsibility, 30 CRITICAL SOCIOLOGY 669, 675 (2004).

${ }^{15}$ See Ans Kolk, A Decade of Sustainability Reporting: Developments and Significance, 3 INT'L J. ENVIRONMENT \& SustAinABLE DEVEL. 51, 52 Figure 1 (2004). KPMG has changed the format of the report since its original 1993 report on corporate responsibility reporting, so direct comparisons are not possible between the Global 250 in 1993 and the Global 250 in 2013.

${ }^{16}$ KPMG, The KPMG Survey of CR Reporting 2013, at 10, available at http://www.kpmg.com/Global/en/IssuesAndInsights/ArticlesPublications/corporateresponsibility/Documents/corporate-responsibility-reporting-survey-2013-exec-summary.pdf (last visited March 5, 2015).

${ }^{17}$ See id.

${ }^{18}$ See id.at 11. The Global Reporting Initiative is now in its fourth iteration. It has been developed by, and is used by, thousands of companies, governments, and non-profit entities around the world to report on the economic, environmental, social and governance effects of entities' actions. See Global Reporting Initiative, available at http://www.globalreporting.org.
} 
slightly over half (59\%) of the Global 250 now have their reports "assured,” most often (twothirds of the time) by the specialist bureaus of the major accountancy firms. ${ }^{19}$

In addition to the quantity of corporate responsibility reporting, KPMG also evaluates the quality of reporting. Here, European companies generally do substantially better than those in Asia or the Americas (average quality scores of 71 out of 100 in Europe versus 54 for companies in the Americas and 50 in Asia Pacific). ${ }^{20}$ Within the Global 250, companies are starting to see more opportunities than risks from social and environmental factors, such as for the development of new products and services. Eighty-seven percent of the Global 250 identify climate change, material resource scarcity and trends in energy and fuel as "megatrends" that will affect their business. ${ }^{21}$ Ultimately KPMG concludes that “[m]any companies no longer see corporate responsibility as a moral issue, but as core business risks and opportunities.” ${ }^{22}$ This conclusion is consistent with the views of prominent management academics Michael Porter and Mark Kramer, ${ }^{23}$ and Abagail McWilliams and Donald Siegel, ${ }^{24}$ each of whom (among others) has argued for companies to use corporate responsibility initiatives as part of their business strategies to promote competitive advantage.

\section{B. Substantive Corporate Responsibility Initiatives}

1. Private Initiatives

\footnotetext{
${ }^{19}$ See KPMG 2013 Report, supra note 16, at 11.

${ }^{20}$ See id. at 14.

${ }^{21}$ See id. at 14-15.

22 See id. at 15.

23 See Michael E. Porter and Mark R. Kramer, Strategy and Society: The Link Between Competitive Advantage and Corporate Social Responsibility, HARV. BuS. REV. 78 ( DEC. 2006).

${ }^{24}$ See Abagail McWilliams \& Donald S. Siegel, Creating and Capturing Value: Strategic Corporate Social Responsibility, Resource-Based Theory, and Sustainable Competitive Advantage, 37 J. OF MANGMT. 1480 (2011).
} 
The focus on expanded ESG disclosure has occurred concomitantly with the proliferation of transnational, voluntary standards for what constitutes responsible corporate action. Thus, over the past two decades such standards have been developed by states; public/private partnerships; multi-stakeholder negotiation processes; industries and companies; institutional investors; functional groups such as accountancy firms and social assurance consulting groups (many of which did not exist more than ten years ago); NGOs; and non-financial ratings agencies. ${ }^{25}$ Standards have been developed in just about every industry, from apparel ${ }^{26}$ to chemicals, ${ }^{27}$ extractives such as oil, gas and minerals ${ }^{28}$ to conflict-free diamonds; ${ }^{29}$ sustainable fisheries ${ }^{30}$ and forestry $;{ }^{31}$ project finance ${ }^{32}$ and fair-trade goods such as coffee, tea, cocoa and cotton, ${ }^{33}$ to name just a few examples. Thousands of individual companies have adopted voluntary codes of conduct establishing standards for responsible behavior, and some companies then engage third-

\footnotetext{
${ }^{25}$ See Benedict Kingsbury, Nico Krisch, \& Richard B. Stewart, The Emergence of Global Administrative Law, 68 L. \& CONTEMP. PROBS. 15 (2005). The implications of these standards for theories of corporate governance, regulation, and economic development are profound, some of which the author has explored in prior work. See Cynthia A. Williams \& John M. Conley, An Emerging Third Way? The Erosion of the Anglo-American Shareholder Value Construct, 38 CORN. INT’L. J. J. 493(2005).

${ }^{26}$ See, e.g., The Fair Labor Associations, http://www.FLA.org, or the Workers’ Rights Consortium, http://www.workersrights.org. For a discussion of these and other standards for the global supply chain in the apparel industry, see Dara O'Rourke, Outsourcing Regulation: Analyzing Non-Governmental Systems of Labor Standards and Monitoring, 31 POL’Y STUD. J. 1 (2003).

${ }^{27}$ See Responsible Care, http://www.canadianchemistry.ca/responsible_care/index.php/en/responsible-care-history; Jean M. Belanger, Responsible Care in Canada: The Evolution of an Ethic and a Commitment, 27 CHEM. INT'L 2 (March-April) 2005. The standards developed for responsible industrial chemicals production are in place in over 60 countries, as of 2015, and now include greenhouse gas reporting and assurance.

${ }^{28}$ See The Voluntary Principles on Security and Human Rights, available at http://www.voluntaryprinciples.org.

${ }^{29}$ See The Kimberly Process, http://www.kimberleyprocess.com.

30 See, e.g., the Marine Stewardship Council certification process, http://www.msc.org.

${ }^{31}$ See Forest Stewardship Council: Principles and Criteria for Forest Stewardship, available at http://www.fsc.org. Competition between the forest standards promulgated by business versus those promulgated by NGOs has been extensively studied by leading students of regulation and political theory. See BENJAMIN CASHORE, GraEME AulD \& DeANnA NEWSOM, GOVERning Through MARKETS: Forest CERTIFICATION AND THE EMERGENCE OF NONStATE AuthORITY (Yale Univ. Press 2004); Errol Meidinger, The Administrative Law of Global Private-Public Regulation: the Case of Forestry, 17 EUR. J. OF INT’L LAW 47, 51 (2006).

${ }^{32}$ See The Equator Principles, http://www.equator-principles.com. See also John M. Conley \& Cynthia A. Williams, Global Banks as Global Sustainability Regulators: The Equator Principles, 33:4 J. L. \& POLICY REV. 542 (2011).

33 See http://www.fairtrade.net/certification_mark.html for an overview of the fair trade requirements.
} 
party certifiers to ensure that their suppliers and subsidiaries are meeting those standards. ${ }^{34}$

Multi-sector codes have also been developed with standards that are designed to apply across industries. Of particular note here is Social Accountability 8000, which is based on the International Labor Organization (ILO)'s Fundamental Principles and Rights at Work, ${ }^{35}$ but adds a commitment to a living wage, and a commitment to compliance with U.N. international human rights protections. ${ }^{36}$ SA 8000 also includes a requirement for independent monitoring of code compliance prior to certification that specific productive facilities meet the SA8000 standards. Another multi-sector example is the Ethical Trading Institute, which is a London-based tri-partite labor, industry and NGO organization working to incorporate ILO protections into supply chains for products bound for the Western markets. ${ }^{37}$ ETI works in a deliberative fashion, using monitoring, evaluation and on-going learning to both improve standards for the 9.8 million people incorporated into the 70 companies’ supply chains (as of 2015), but also to teach workers their rights and how to advocate for them independently. ${ }^{38}$

\section{Multilateral Initiatives}

A number of significant multilateral instruments have also been developed or recently strengthened by organizations comprised of government representatives. While these instruments do not establish binding treaty obligations, they do articulate governments'

34 See Margaret M. Blair, Cynthia A. Williams \& Li-Wen Lin, The New Role for Assurance Services in Global Commerce, 33 J. CORP. L. 325 (2008). The University of Minnesota Law School, under the leadership of international human rights scholar Prof. David Weissbrodt, has an extensive collection of human rights materials online, including copies of hundreds of firms' codes of conduct. See https://www1.umn.edu/humanrts/business/codes.html.

35 The International Labour Organization's 1998 Declaration on Fundamental Principles and Rights at Work focusses on four core rights: freedom of association and rights to collective bargaining, freedom from forced labor or prison labor, freedom from child labor exploitation and non-discrimination. See International Labour Organization, available at http://www.ilo.org/declaration/lang--en/index.htm.

${ }^{36}$ See Social Accountability 8000, available at http://www.sa-intl.org.

${ }^{37}$ See Ethical Trading Initiative, available at http://www.ethicaltrade.org.

${ }^{38}$ See Ethical Trading Initiative, available at http://www.ethicaltrade.org/news-and-events/press-resources/eti-keyachievements. 
expectations of responsible corporate action. Four are of particular note: the OECD’s Guidelines for Multinational Enterprises; the ISO 26,000 Corporate Responsibility standards; the U.N.'s Global Compact; and the U.N.’s more recent “Protect, Respect and Remedy” framework articulating states’ and companies’ human rights responsibilities.

The OECD’s Guidelines, initially promulgated in 1976 and most recently amended in 2011, encourage companies to promote sustainable development, and include standards based on ILO and U.N. treaty obligations, including standards of transparency, labor protection, international human rights protection, responsible supply chain management, environmental protection, antibribery standards and fair tax contributions (added in 2011 and unique among international corporate responsibility standards). ${ }^{39}$ A number of aspects of the OECD approach are of particular importance. First, the standards are developed through tri-partite participation of governments (through the OECD itself), business (the Business and Industry Advisory Committee to the OECD) and labor (the Trade Union Advisory Committee to the OECD). This approach is typical of the "social partners" view of economic life in Europe. Second, the OECD is starting to develop sector-specific guidance for responsible business conduct in a number of areas: agricultural supply chains, financial sector due diligence, textile and garment supply chains, extractive sector stakeholder engagement and mineral supply chains. Third, the OECD countries, which include most of the developed economies (excepting Brazil, Russia, India and China), all commit to establish National Contact Points (NCPs) to whom challenges may be brought where individuals feel their OECD rights have been violated. Labor, in particular, has

\footnotetext{
${ }^{39}$ See Guidelines for Multinational Enterprises, available at http://www.oecd.org/corporate.mne.
} 
been proactive in using these NCPs to address violations, and by so doing a record of global labor rights and responsibilities is slowly being developed. ${ }^{40}$

The International Standards Organization (ISO), which has developed thousands of technical standards since its establishment after World War II, developed the ISO 26,000 standard for corporate responsibility in 2010, after five years of consultation among standards bodies. ${ }^{41}$ Unlike most of its standards, against which certification can occur, ISO 26,000 is not a standard to provide guidance for certification. It does, however, provide a useful definition of corporate responsibility:

CSR is the responsibility of an organization for the impacts of its decisions and activities on society and the environment, through transparent and ethical behavior that contributes to sustainable development, including health and the welfare of society, takes into account the expectations of stakeholders, is in compliance with applicable laws and with international norms of behavior, and is integrated throughout the organization and practiced in its relationships. ${ }^{42}$

ISO 26,000 is important as evidence of the developing global norm of corporate responsibility: developed with representation from 90 countries and 40 international or regional organizations, it was drafted with input from consumers, governments, industry, labor, NGOs and "service, support, research, academics and others, ${ }^{43}$ and so can credibly claim to represent a global consensus about companies’ social responsibilities. To read the specific standards one must buy them (somewhat ironic where one responsibility principle is transparency, but an apparently successful business model), but an outline of the topics is available. ISO 26,0000 defines general principles of accountability, transparency, ethical behavior, respect for stakeholder interests, for

\footnotetext{
${ }^{40}$ See John Evans, Organizing workers globally: the need for public policy to regulate investment, in THE EMBEDDED FIRM: CORPORATE GOVERNANCE, LABOR, AND FINANCE CAPITALISM (Cynthia A. Williams and Peer Zumbansen, eds.)(Cambridge Univ. Press 2011), at 343-353.

${ }^{41}$ See ISO 26,000-Social Responsibility, available at http://www.iso.org/iso/home/standards/iso26000.htm.

${ }^{42}$ See id.

${ }^{43}$ See id.
} 
rule of law, for international norms and human rights as the field of corporate responsibility; and core subjects include governance, human rights, labor practices, the environment, fair operating practices, consumer issues, and community involvement. ${ }^{44}$

The United Nations began its work on corporate responsibility in 2000 under Secretary General Kofi Annan with the Global Compact, a policy initiative in which businesses commit to respect ten principles that cover four areas of concern (international human rights, labor protection, environmental protection, and anti-corruption). ${ }^{45}$ By 2015, 12,000 businesses, academic institutions, and NGOs in 140 countries had signed onto the Global Compact. Governance efforts are underway to make corporate commitments to the Global Compact framework meaningful, including requirements for participants to communicate annually on their progress regarding the four areas of concern. Still, by 2008 close to $15 \%$ of companies had been de-listed from the Global Compact for failing to report on their progress, and the Global Compact continues to be criticized for its lack of specificity. ${ }^{46}$

Among multilateral frameworks, the U.N.’s Guiding Principles on Business and Human Rights, adopted by the U.N. Human Rights Council in 2011, seems to have the greatest potential to develop into a baseline global legal framework for companies' social responsibilities. (The OECD Principles only apply to companies in or from adhering countries.) The U.N. Guiding Principles set out the core spheres of obligation for states and companies with respect to human rights: states have the duty to protect their citizens from violations by third parties, including companies, by promulgating laws and regulations; companies have the responsibility to act with

\footnotetext{
${ }^{44}$ See Guidance on ISO 26,0000, available at https://www.iso.org/obp/ui/\#iso:std:iso:26000:ed-1:v1:en:sec:A.

${ }^{4}$ See U.N. Global Compact Annual Review 2010, available at http://www.unglobalcompact.org/docs/news_events/8.1/UNGC_Annual_Review_2010.pdf.

${ }^{46}$ See Jette Steen Knudsen, Which Companies Benefit Most from U.N. Global Compact Membership?, available at http://www.EuropeanBusinessReview.com/?p=3167 (citing statistics, and asserting that the Global Compact is primarily useful for large companies to fill a governance void as they operate in less developed countries).
} 
due diligence to respect citizens' human rights; and both have the duty to provide access to remedies for victims. Developed after the failure in 2004 of the U.N. Human Right's Commission's Draft Norms on the Responsibilities of Transnational Corporations and Other Business Enterprises with Regard to Human Rights, which "business vehemently opposed," ${ }^{47}$ the Protect, Respect, and Remedy framework was developed in a six-year process led by Prof. John Ruggie of Harvard University. The international human rights obligations applicable to companies through the Guiding Principles include those in the Universal Declaration of Human Rights, the International Covenants on Civil and Political Rights and on Economic, Social and Cultural Rights, and the Core Conventions of the ILO. ${ }^{48}$ The state duty to protect human rights is now being incorporated into many European and other countries by the establishment of National Action Plans to disseminate and implement the Guiding Principles. ${ }^{49}$ At the same time, an NGO called the Business and Human Rights Resource Centre, supported by the UK and German governments, has launched a ranking of companies' human rights records in response to the Guiding Principles. ${ }^{50}$ The combination of global standards supported by and being implemented by a broad array of governments, a standards-development process that was inclusive, transparent and well-balanced between companies, labor and NGOs, and a dedicated NGO collecting data and publicizing it, gives the U.N. Guiding Principles the potential to become the de facto global corporate responsibility standard.

\section{SIGNIFICANT LEGAL REQUIREMENTS}

\footnotetext{
${ }^{47}$ See U.N. Guiding Principles, available at http://www.reports-and-materials.org/sites/default/files/reports-andmaterials/Ruggie-protect-respect-remedy-framework.pdf.

${ }^{48}$ See id.

${ }^{49}$ See Guidelines for the U.N. Guiding Principles, available at http://www.ohchr.org/EN/Issues/Business/Pages/NationalActionPlans.aspx.

${ }^{50}$ See Phil Bloomer, Human Rights and Big Business: new ranking aims to drive race to the top, The Guardian (14 Jan. 2015).
} 
For the most part, corporate responsibility standards are voluntary, with the exception of new legislation in India, which has required companies to establish a corporate responsibility committee of the board and contribute $2 \%$ of net profits to corporate responsibility initiatives as of 2014, ${ }^{51}$ building upon strong cultural foundations for the social obligations of successful companies (and people) in India. ${ }^{52}$ That said, many of the topics that corporate responsibility addresses are subject to domestic regulation, such as labor rights, environmental protection, consumer protection, anti-discrimination or anti-bribery. And these regulatory standards have implications for the degree to which voluntary corporate responsibility initiatives are necessary to fill important gaps, either in a domestic or transnational context. As has been argued by Dirk Matten and Jeremy Moon, in countries with stakeholder corporate governance systems and more expansive social welfare arrangements, corporate responsibility is “implicit” in doing business according to law, so companies do not need to be as “explicit” about taking on social responsibilities, as do leading companies in more shareholder-oriented countries. ${ }^{53}$ As will be discussed below, recent empirical evidence suggests that these underlying regulatory standards effectively shape the sustainability culture within countries, and have both a strong effect on how companies handle corporate responsibility issues and a strong effect on the sustainability

\footnotetext{
${ }^{51}$ See Price Waterhouse Coopers, Handbook on Corporate Social Responsibility in India, available at http://www.pwc.in/assets/pdfs/publications/2013/handbook-on-corporate-social-responsibility-in-india.pdf. ${ }^{52}$ See Peter Cappelli, Harbir Singh, Jitendra Singh \& Micael Useem, The India Way: Lessons for the U.S., 24 ACAD. MNGMT. PERSPECTIVES 6 (2010)(arguing that business managers in India eschew explicit concern with shareholder value, but invest in employee training, employee empowerment, and a social mission, leading to strong growth and successful companies). The Tata Steel Company is one example, among many, of companies with extensive community social responsibility and employee welfare and training initiatives going back over a century. See http://www.tatasteel.com/corporate/heritage/a-century-of-trust.asp.

${ }^{53}$ See Dirk Matten \& Jeremy Moon, "Implicit" and "explicit" CSR: A conceptual framework for a comparative understanding of corporate social responsibility, 33:2 ACAD. MNGMT. REV. 404 (2008).
} 
outcomes at the country level. ${ }^{54}$ To the extent that governments have regulated corporate responsibility per se, though, such regulation is focused on disclosure.

By 2015, many European countries or their stock exchanges, and the EU itself, require some environmental or social disclosure, to varying degrees of specificity. ${ }^{55}$ The EU's requirement is a directive that entered into force on 6 December 2014; member states will need to transpose it into national legislation within two years. ${ }^{56}$ It will require approximately 6,000 large companies and “public interest organizations," such as banks and insurance companies, to "prepare a nonfinancial statement containing information relating to at least environmental matters, social and employee-related matters, respect for human rights, anti-corruption and bribery matters." 57 This requirement builds upon EU accounting rules (the EU Accounts Modernization Directive) that have, since 2003, required companies to report on environmental and labor issues "to the extent necessary” to provide investors with an accurate view of the company’s financial position and the risks to that position. ${ }^{58}$

In addition to the new EU non-financial disclosure requirements, the Nordic countries have been leaders in requiring corporate reporting that is more comprehensive than the reporting required by the EU’s 2003 Accounts Modernization Directive. Since 2008, public companies in

\footnotetext{
${ }^{54}$ See Part IV, D, infra.

${ }^{55}$ See Beate Sjåfjell \& Linn Anker Sørensen, Directors Duties and Corporate Social Responsibility, 25, in BoARDS OF DIRECTORS IN EUROPEAN COMPANIES: RESHAPING AND HARMONIZING THEIR ORGANISATION AND DUTIES (Hanne Birkmose, Mette Neveille and Karsten Engsig Sørensen, eds. Kluwer Law Int'l 2013/2014), available at http://papers.ssrn.com/sol3/papers.cfm?abstract_id=2322680.

${ }^{56}$ See Directive 2014/95/EU of the European Parliament and of the Council of 22 October 2014, amending Directive 2013/34/EU as regards disclosure of non-financial and diversity information by certain large undertakings and groups, Official Journal of the European Union L330/1-330/9.

${ }^{57}$ See id. at 96.

58 See Beate Sjåfjell \& Linn Anker Sørensen, Directors Duties and Corporate Social Responsibility,25, in BoARDS OF DIRECTORS IN EUROPEAN COMPANIES: RESHAPING AND HARMONIZING THEIR ORGANISATION AND DUTIES (Hanne Birkmose, Mette Neveille and Karsten Engsig Sørensen, eds. Kluwer Law Int'l 2013/2014), available at http://papers.ssrn.com/sol3/papers.cfm?abstract_id=2322680. For further discussion of the 2003 Accounts Modernization Directive, see Cynthia A. Williams \& John M. Conley, Triumph or Tragedy? The Curious Path of Corporate Disclosure Reform in the UK, 31:2 WILLIAM \& MARY ENV. L.J. 317 (2007).
} 
Sweden must make a sustainability report consistent with GRI (the Global Reporting Initiative). ${ }^{59}$ Since January 2009, approximately 1,100 large companies in Denmark, as well as institutional investors and loan providers, have been required to publish an annual corporate responsibility report, following a 2008 government Action Plan on Corporate Responsibility. ${ }^{60}$ Companies may use their annual reporting to the U.N. Global Compact as the framework for their public disclosure, and institutional investors may report on their incorporation of the Principles of Responsible Investment (PRI) developed by the U.N. Environment Program. ${ }^{61}$ And as of 1 July 2013, Norwegian companies must report on labor issues, gender equality, antidiscrimination and environmental issues, including reporting on what they are doing to incorporate these issues and human rights concerns into management practices. ${ }^{62}$

These examples are indicative of a global trend towards required corporate responsibility reporting. According to a 2015 report by the Initiative for Responsible Investment of the Hauser Institute for Civil Society at the Kennedy School, Harvard University, 23 countries have enacted legislation within the last 15 years to require public companies to issue reports including environmental and/or social information. ${ }^{63}$ These countries include Argentina, China, Denmark, the EU, Ecuador, Finland, France, Germany Greece, Hungary, India, Indonesia, Ireland (specific to state-supported financial institutions after the 2008 financial crisis), Italy, Japan, Malasia, The

\footnotetext{
${ }^{59}$ See Jan Bertil Anderson and Frida Segenmark, Sustainable Companies: Barriers and Possibilities in Swedish Company Law, Univ. of Oslo Res. Paper No. 2013-09 (April 11, 2013), available at http://www.ssrn.com/abstract=2248584.

${ }^{60}$ See Karin Buhmann, Company Law as an Agent for Migration of CR-Related International Law into Company Self-Regulation? The Case of the CR Reporting Requirement, 8:2-3 EUR. COMPANY LAW 65, 68 (2011).

${ }^{61}$ See id. For more information on the PRI, see United Nations Environment Program Principles for Responsible Investment, available at http://www.unpri.org/about-pri/.

${ }^{62}$ See Sjåfjell \& Sørensen, supra note 58, at 26-27.

${ }^{63}$ See Initiative for Responsible Investment, Corporate Social Responsibility Disclosure Efforts by National Governments and Stock Exchanges (March 12, 2015), available at http://hausercenter.org/iri/wpcontent/uploads/2011/08/CR-3-12-15.pdf.
} 
Netherlands, Norway, South Africa, Spain, Sweden, Taiwan, and the U.K. ${ }^{64}$ Of these countries, France is particularly noteworthy, having been a leader by requiring publicly-listed companies to report data on 40 labor and social criteria since 2002, followed by requirements in 2009 for companies with more than 500 employees in high-emitting sectors to publish their greenhousegas (GHG) emissions. ${ }^{65}$

In addition to these reporting initiatives, seven stock exchanges require social and/or environmental disclosure as part of their listing requirements: Australia's ASX, Brazil's Bovespa, India’s Securities and Exchange Board, the Bursa Malasia, Oslo’s Børs, the Johannesburg Stock Exchange, and the London Stock Exchange. ${ }^{66}$ Moreover, seven countries have enacted policies following those of the U.K. and Sweden, which since 2000 have required pension funds to disclose the extent to which the fund incorporates social and environmental information into their investment decisions. ${ }^{67}$ These countries include Australia, Belgium, Canada, France, Germany, Italy, and Japan. ${ }^{68}$

Notably missing from any of these lists of comprehensive ESG disclosure is the United States, which does have specific disclosure requirements in certain regulatory contexts but no general ESG disclosure framework. Since 1986, the Environmental Protection Agency has required facility-by-facility disclosure concerning the release into the environment and/or

\footnotetext{
${ }^{64}$ See id.

${ }^{65}$ See id., citing the New Economic Regulations Act in France, 2002.

${ }^{66}$ See id.

${ }^{67}$ For a discussion of this requirement in the U.K., and other early social and environmental disclosure requirements, see Cynthia A. Williams \& John M. Conley, An Emerging Third Way?: The Erosion of the Anglo-American Shareholder Value Construct, 38 CORNELL INT'L L.J. 493 (2005)(arguing that differences in the "shareholder wealth maximizing" norm between the U.K. and U.S. were substantial enough to cast doubt on the idea of an "Anglo-American corporate governance" system).

${ }^{68}$ See Initiative for Responsible Investment report, supra note 63.
} 
management through recycling of over 650 chemicals through the Toxic Release Inventory. ${ }^{69}$

The U.S. Securities and Exchange Commission (SEC) requires substantial corporate governance disclosure from its publicly-listed companies, as do most countries. Yet, generalized requirements for environmental or social disclosure tend to be narrower than those described above.

Current SEC regulations require disclosure of environmental litigation against any government agency where a penalty of $\$ 100,000$ is sought, ${ }^{70}$ and the SEC has issued guidance for listed companies regarding the extent to which they should disclose climate risks to their future profitability, either from physical changes associated with climate change, or from regulatory initiatives designed to mitigate climate risk. ${ }^{71}$

Four relevant disclosure requirements (with rule-making directives to the SEC) were enacted as part of the Dodd-Frank Wall Street Reform and Consumer Protection Act of 2010, each targeting an aspect of a company's social record: the ratio of the CEO's total pay to the median employee pay; ${ }^{72}$ mine safety disclosure; ${ }^{73}$ “conflict minerals” disclosure where tin; tantalum,

\footnotetext{
${ }^{69}$ See Toxic Release Inventory, available at http://www2.epa.gov/toxics-release-inventory-tri-program/learn-abouttoxics-release-inventory.

${ }^{70}$ See Reg. S-K, Instructions to Item 103, No. 5(C), 17 C.F.R. § 229.103 (2015). For a discussion of this requirement, as well as an analysis of the statutory authority of the SEC to require much more extensive social and environmental disclosure, see Cynthia A. Williams, The Securities and Exchange Commission and Corporate Social Transparency, 112 HARV. L. REV. 1197 (1999).

${ }^{71}$ See Commission Guidance Regarding Disclosure Related to Climate Change, Rel. 33-9106, 34-61469 (Feb. 8, 2010), available at https://www.sec.gov/rules/interp/2010/33-9106.pdf.

72 See Dodd-Frank Wall Street Reform and Consumer Protection Act of 2010 (“Dodd-Frank"), § 953(b)(2). The SEC's proposed rule to implement this provision was published on September 18, 2013 a 3-2 divided vote, but the final rule has yet to be promulgated as of April, 2015. Pay Ratio Disclosure Proposed Rule, Rel. No. 33-9452, 3470443 (Sept. 18, 2013), available at https://www.sec.gov/rules/proposed/2013/33-9452.pdf.

${ }^{73}$ See Dodd-Frank Wall Street Reform and Consumer Protection Act of 2010 ("Dodd-Frank"), § 1503. The Securities and Exchange Commission has implemented this requirement as Item 104 of Regulation S-K, 17 C.F.R. § 229.104. This section was added to Dodd-Frank after an explosion in April, 2010, at the Upper Big Branch Mine in West Virginia, killed 29 miners. It soon became clear that Massey Energy, the owner of the mine, had a practice of ignoring the Federal Mine Safety and Health Act of 1977, having received over 1300 notifications of violations about that particular mine in the years leading up to the explosion. Democracy Now, Massey Energy Mine Cited for
} 
tungsten or gold from the Democratic Republic of the Congo or neighboring countries were incorporated into listed companies’ products; ${ }^{74}$ and "publish what you pay” transparency disclosure for extractive company payments to host countries. ${ }^{75}$ These latter two disclosure provisions have been challenged in litigation by the National Association of Manufacturers (challenging conflict mineral disclosure), and the American Petroleum Institute (challenging publish what you pay), joined in both instances by the U.S. Chamber of Commerce.

The SEC’s implementing rule on conflict mineral disclosure, requiring listed companies to engage in a due diligence process to determine if their supplies of the named minerals were from mines supporting armed rebels or the Congolese army, was generally upheld by the District Court $^{76}$ and Court of Appeals for the District of Columbia Circuit, with one exception identified by the Court of Appeals. ${ }^{77}$ That exception held that required language in reports to the SEC and on a company's website that minerals "have not been found to be DRC conflict free” where a company’s due diligence could not exclude the possibility of conflict minerals in their supply chains violated companies’ First Amendment rights. ${ }^{78}$ This aspect of the Court of Appeals' decision is being further reviewed by the Court of Appeals, ${ }^{79}$ but the rest of the rule has gone into effect, requiring companies to evaluate whether their supplies are conflict free and to report on their due diligence procedures, without using the offending required language.

1300+ Safety Violations in Years Leading up the Deadly Explosion, April 7, 2010, available at http://www.demoCRacynow.org/2010/4/7/massey_energy_mine_cited_for_1

${ }^{74}$ See Dodd-Frank, § 1502, enacted as 15 U.S.C. § 13(p).

${ }^{75}$ See Dodd-Frank, § 1504, enacted as 15 U.S.C. § 13(q).

${ }^{76}$ National Association of Manufacturers, Inc. v. SEC, 956 F.Supp.2d 43 (D.D.C. 2013).

77 See National Association of Manufacturers, Inc. (“NAM”) v. SEC, 748 F.3d 359 (D.C. Cir. 2014).

${ }^{78}$ See NAM , 748 F.3d at 372-373.

${ }^{79}$ Soon after the Court of Appeals decision in NAM v. SEC, the Court of Appeals for the District of Columbia Circuit decided another disclosure case, en banc, holding against a similar claim by companies (that required country-of-origin disclosure for meat products violated their First Amendment rights), and using a lower level of constitutional scrutiny ("rational basis") than had been applied in the NAM litigation challenging the conflict minerals disclosure. See American Meat Institute v. U.S. Department of Agriculture, 730 F.3d 18 (D.C. Cir. 2014)(en banc). After American Meat Institute the SEC obtained further review of the conflict minerals disclosure, and is seeking to persuade the court to uphold its entire rule using the rational basis process of analysis. 
The 2012 "publish what you pay” rule promulgated by the SEC in response to Dodd-Frank was vacated by the District Court for the District of Columbia Circuit for failing to include any exemptions for public disclosure where host countries prohibit it (such as Angola, Cameroon, China and Qatar), and for interpreting Dodd-Frank to require public disclosure rather than considering disclosure only to the SEC. ${ }^{80}$ As of March, 2015, the SEC had not reissued the rule.

Generally, though, there is a clear trend towards an increasing number of environmental and social disclosure requirements around the world. A report by KPMG, UNEP, GRI and the Unit for Corporate Governance in Africa that identified individual reporting initiatives in 45 countries found 180 such initiatives in 2013, three times the number they had found in $2006 .{ }^{81}$ Such reporting initiatives included ESG/sustainability disclosure frameworks, such as GRI; requirements or recommendations for disclosure of individual topics (e.g., GHGs) or addressed to specific industries (e.g., mining); or were standards regarding sustainability assurance. Of these 180 reporting initiatives, 72\% were mandatory, compared to 58\% mandatory in 2006 .

\section{EMPIRICAL FINDINGS}

The trends described above of increasing voluntary corporate ESG disclosure, increasing numbers of voluntary corporate responsibility standards and multilateral frameworks, and increasing numbers of jurisdictions imposing standards for required ESG disclosure suggest that corporate responsibility is becoming important in the institutional and normative frameworks shaping companies' actions. Notwithstanding these trends, the concept of corporate responsibility remains contested from a number of perspectives. In the following sections, some

\footnotetext{
${ }^{80}$ See American Petroleum Institute v. SEC, No. 12-1398 (D.D.C. July 2, 2013).

${ }^{81}$ See KPMG, UNEP, Global Reporting Initiative and Unit for Corporate Governance in Africa, Carrots and Sticks: sustainability reporting policies worldwide 8 (2013), available at https://www.globalreporting.org/resourcelibrary/carrots-and-sticks.pdf.
} 
empirical evidence about these trends in relation to institutions of corporate governance will be discussed, followed by a number of critical perspectives.

Two caveats, however, with regard to this discussion of the interaction of corporate responsibility and corporate governance. The topic of corporate responsibility has been given increasing academic attention in the past decades, as this table prepared by Timothy Devinney, University Professor of International Business at the University of Leeds, indicates. This table shows the number of published articles on corporate responsibility within various fields, based on a database Devinney constructed.

\begin{tabular}{|l|c|c|c|c|c|}
\hline \multicolumn{1}{|c|}{ Area } & $<\mathbf{1 9 9 0}$ & $\begin{array}{c}\mathbf{1 9 9 1 -} \\
\mathbf{1 9 9 5}\end{array}$ & $\begin{array}{c}\mathbf{1 9 9 6 -} \\
\mathbf{2 0 0 0}\end{array}$ & $\begin{array}{c}\mathbf{2 0 0 1 -} \\
\mathbf{2 0 0 5}\end{array}$ & $\begin{array}{c}\mathbf{2 0 0 6}- \\
\mathbf{2 0 1 0}\end{array}$ \\
\hline Environmental Sciences & 2 & 0 & 2 & 13 & 61 \\
\hline Economics & 19 & 6 & 9 & 46 & 174 \\
\hline Management & 189 & 149 & 217 & 604 & 1460 \\
\hline Sociology & 14 & 4 & 10 & 105 & 295 \\
\hline Psychology & 3 & 0 & 2 & 6 & 17 \\
\hline Law & 23 & 3 & 11 & 50 & 153 \\
\hline
\end{tabular}

Source: Timothy M. Devinney’s Database of Articles on Corporate Responsibility ${ }^{82}$

The following discussion aims to bring forward a number of the more evocative empirical research findings about corporate governance influences on corporate responsibility, particularly those with implications for the future of this field. It clearly does not purport to be a comprehensive review of this burgeoning literature. Second, the empirical literature on corporate responsibility is equivocal in many respects, as will be discussed below. This is arguably not terribly different from the equivocal results of corporate governance research generally as Ruth Aguilera, Kurt Desender, Michael Bednar and Jun Ho Lee have shown in an argument for better understanding the effects of external corporate governance (law, the market

\footnotetext{
${ }^{82}$ It should be noted that some significant number of articles in psychology, particularly industrial and organizational psychology, are published in management journals.
} 
for corporate control, external auditors, stakeholder activism, ratings agencies and the media) on internal corporate governance and financial results. ${ }^{83}$ As with corporate governance, equivocal empirical results here simply suggest there is more work to be done.

\section{A. Corporate Responsibility and Financial Performance}

One of the perennial debates in this field is whether corporate responsibility initiatives lead to better firm-level financial performance, the "business case" for corporate responsibility. ${ }^{84}$ There are a number of aspects to this debate, but two primary issues have been, first, whether corporate responsibility initiatives pay off, or whether instead they are a waste of money and evidence of unaddressed agency costs; and second, if financial performance is found to be better in firms with robust responsibility initiatives, which way does causation go? Do betterperforming firms invest in corporate responsibility because they have higher slack resources, or do the investments come first and the better financial results follow?

The research addressing both of these issues has led to a welter of conflicting results, which is likely due to three primary factors. First, the breadth of issues encompassed within “corporate responsibility” means different studies are very often looking at different things, while using the same generic labels, as Judith Walls, Pascual Berrone and Philip Phan have argued in narrowing their own scope of quantitative analysis, as discussed below. ${ }^{85}$ Moreover, there are different mechanisms by which corporate responsibility initiatives may contribute to a company’s results, as discussed by Archie Carroll and Kareem Shabama in arguing for a

\footnotetext{
${ }^{83}$ See Ruth V. Aguilera, Kurt Desender, Michael K. Bednar \& Jun Ho Lee, Connecting the Dots: Bringing External Corporate Governance into the Corporate Governance Puzzle, ACAD. OF MNGMT. ANNALs 2015.

${ }^{84}$ See Archie B. Carroll \& Kareem M. Shabama, The Business Case for Corporate Social Responsibility: A Review of Concepts, Research and Practice, INT’L J. OF MNGMT. REVs. 85 (2010).

${ }^{85}$ See Judith A. Walls, Pascual Berrone \& Philip H. Phan, Corporate Governance and Environmental Performance: Is there Really a Link?, 33 STRAT. MNGMT. J. 885, 886 (2012) for further discussion of this point.
} 
broader concept of "the business case” for corporate responsibility. ${ }^{86}$ These differing mechanisms, including "business benefits of (1) reducing costs and risks; (2) strengthening legitimacy and reputation; (3) building competitive advantage; and (4) creating win-win situations through synergistic value creation, ${ }^{, 87}$ would affect results depending on the type of corporate responsibility issue and initiative being examined, the size of the firm, the industry, and the social and legal context. ${ }^{88}$

Second, there are mediating variables that until recently were not being carefully disaggregated. A widely-cited study by Abagail McWilliams and Donald Siegel from 2000 that discusses the equivocal financial results in studies of corporate responsibility is based on this point, showing that R\&D intensity and advertising intensity of industries explain any significant financial out-performance from corporate responsibility, while recognizing close correlations between corporate responsibility and R\&D and advertising. ${ }^{89}$ As studies have become more sophisticated in identifying the mediating variables, the results are starting to be more consistent in showing positive financial results from corporate responsibility.

Third, until recently the data were not very good. Early studies had only a firm's own disclosure to "measure” a firm's social or environmental performance, and some of that disclosure was undoubtedly exaggerated. Today there are multiple databases collating much better quantitative and qualitative sources of information about firms' actual social and environmental performance — such as the data Bloomberg sells to its clients—and the misspecification issues are well-known and are being addressed by targeted studies. As a consequence, certain results are emerging that substantiate the early (2003) meta-analytic result

\footnotetext{
${ }^{86}$ See Carroll \& Shabama, supra note 84, at 92.

${ }^{87} \mathrm{Id}$. at 95.

${ }^{88}$ See id.

${ }^{89}$ See Abagail McWilliams and Donald L. Siegel, Corporate Social Responsibility and Financial Performance: Correlation or Misspecification?, 21 STRAT. MNGMT. J. 603 (2000).
} 
of Marc Orlitzky, Frank Schmidt and Sara Rynes that corporate responsibility investments can pay off. ${ }^{90}$ A number of examples follow.

In a paper showing superior corporate responsibility performance from companies in countries with a Scandinavian legal origin, and then German and French legal origins, and the superiority of all three in comparison to the common law countries (results discussed in more detail in Section D below), Hao Liang and Luc Renneboog show that better corporate responsibility performance also increases firm value, as measured by Tobin’s Q. ${ }^{91}$ This finding is consistent with the results of Bob Eccles, Ioannis Ioannou and George Serafeim, who demonstrate that companies with a strategic focus on ESG issues show financial outperformance, and stock market and accounting value premiums, based on eighteen years' worth of observations of 90 matched pairs of high-sustainability versus low-sustainability companies. ${ }^{92}$ As Eccles, Inannou and Serafeim recognize, these are long-term strategies and not consistent with short-term market pressures or results. One can hypothesize that in the United States, where short-term activist shareholders are becoming increasingly powerful, corporate responsibility initiatives will be under pressure. More recent work by Serafeim and colleagues Mozaffar Khan and Aaron Yoon show that management attention to material sustainability risks yields financial outperformance of $3 \%$ to $8 \%$, evaluated within industries using specific concepts

\footnotetext{
${ }^{90}$ This study is a widely-cited (over 3,300 citations to 2015) meta-analysis of 52 prior studies, and it shows better financial performance of firms with better environmental and social records, although the magnitudes of the financial correlations, while statistically significant, are modest. See Marc Orlitzky, Frank L. Schmidt, \& Sara L. Rynes, Corporate Social and Financial Performance: A Meta-Analysis. 24 ORG. STUD. 403 (2003).

${ }^{91}$ See Hao Liang and Luc Renneboog, , Law and Finance: The Foundations of Corporate Social Responsibility, Tilburg University CentER for Economic Research, European Corporate Governance Institute (ECGI) Finance Working Paper No. 394/2013 (Jan. 2014), available at http://papers.ssrn.com/sol3/papers.cfm?abstract_id=2360633. ${ }^{92}$ See Robert G. Eccles, Ioannis Ioannou, \& George Serafeim, the Impact of Corporate Sustainability on Organizational Processes and Performance, 60:11 MNGMT. SCIENCE 2835 (2014).
} 
of industry-relevant materiality being developed in the United States by the Sustainability Accounting Standards Board (SASB). ${ }^{93}$

If some corporate responsibility initiatives lead to better financial performance, in some industries and legal contexts, a follow-on question is why. Here a number of very recent empirical studies show that important mediating variables are innovation and trust. Companies with a longer-term management focus ${ }^{94}$ or a stakeholder orientation ${ }^{95}$ promote innovation within the firm and higher levels of trust of the firm among various external stakeholders. In one study, Caroline Flammer and Aleksandra Kacperczk used a “natural experiment” to demarcate a shareholder from a stakeholder orientation of a firm, which was the enactment in various states of the United States of "other constituency" statutes. ${ }^{96}$ In the law literature, these statutes, which give directors the statutory discretion to consider constituents other than shareholders in making decisions, particularly decisions to resist takeovers, have generally been interpreted to be relatively unimportant, and underutilized, albeit with the potential to create ambiguity regarding directors' duties. ${ }^{97}$ What Flammer and Kacperczk found, however, based on regressions on 159,558 firm year observations, is that measures of innovation — the number of patents issued and the number of citations to those patents-increased significantly (went up between 6.4\% and 6.8\%) in companies in states that enacted an "other constituency" statute. ${ }^{98}$ They interpret

\footnotetext{
${ }^{93}$ See Mozaffar Khan, George Serafeim, \& Aaron Yoon, Corporate Sustainability: First Evidence on Materiality, Harvard Business School Working Paper 15-073 (March 2015), available at http://papers.ssrn.com/sol3/papers.cfm?abstract_id=2575912.

${ }^{94}$ See Caroline Flammer \& Pratima Bansal, Does Long-Term Orientation Create Value? Evidence from a Regression Discontinuity (2014) available at http://papers.ssrn.com/sol3/papers.cfm?abstract_id=2511507 (showing that firms that adopted longer-term executive compensation plans showed an increase in firm value and operating performance after the adoption of those plans).

${ }^{95}$ See Caroline Flammer \& Aleksandra Kacperczk, The Impact of Stakeholder Orientation on Innovation: Evidence from a Natural Experiment, available at http://papers.ssrn.com/sol3/papers.cfm?abstract_id=2353076.

${ }^{96}$ See id.

${ }^{97}$ See American Bar Association, Other Constituency Statutes: Potential for Confusion, 45:4 Bus. LAW. 2253 (1990).

${ }^{98}$ See id. at 23-24.
} 
these results to show that the protections of other constituency statutes allow for greater experimentation within the firm, which results in both more "flops" and more "hits” on which the firm can get a patent. ${ }^{99}$ In another study, Flammer and Pratima Bansal found an increase in firm value after the firm's adopted longer-term management compensation plans, and also found improved operating performance on each of three metrics (return on assets, net profit margin, and sales growth). ${ }^{100}$ In year one after the firm adopted the longer-term plan, operating performance declined, which Flammer and Bansal suggest shows that "increased long-term orientation may take some time to materialize into higher profits.”101 Flammer and Bansal’s results were mediated by increases in innovation after firm's adopted a longer-term orientation, as measured by increasing investment in R\&D; and increases in social capital investments and performance (legitimacy, reputation and trust). ${ }^{102}$

Empirical results from Jodi Surroca, Josep Tribó and Sandra Waddock support the theory that intangibles like innovation are a necessary mediating variable that explain the relationship between corporate responsibility and better financial performance. ${ }^{103}$ Their study shows that corporate responsibility strategies and operating procedures positively influence intangibles of innovation, human capital improvements, reputation and corporate culture, and that these intangibles are significantly related to corporate financial performance. ${ }^{104}$ If the effects on intangibles are statistically “pulled out,” then corporate responsibility performance does not

\footnotetext{
${ }^{99}$ See id.

${ }^{100}$ See Flammer \& Bansal, supra note 93, at 4.

${ }^{101} \mathrm{Id}$.

${ }^{102}$ See id. Social performance is measured using the Kinder, Lydenberg, Domini (KLD) index of social performance. KLD is a socially-responsible investment fund which has collected an extensive database of quantitative and qualitative data since 1991, which data it uses to construct its investment portfolios. KLD's data is widely used in empirical studies of CSR.

${ }^{103}$ See Jordi Surroca, Josep A. Tribó \& Sandra Waddock, Corporate Responsibility and Financial Performance: The Role of Intangible Resources, 31 STRAT. MNGMT. J. 463 (2010).

${ }^{104}$ See id. at 480
} 
show significant effects on corporate financial performance. ${ }^{105}$ These mediating influences are stronger in growth industries versus mature industries, and causality is shown in both directions in both growth and mature industries: better financial performance supports some of the same intangibles and leads to better corporate responsibility performance, and vice versa. ${ }^{106}$ Taken together, Surroca et al. conclude that it is the necessity of the mediating variables that explains many of the mixed results of previous investigations of the business case, and explains some of the modesty of the Orlitzky et al. results in their 2003 meta-analysis. ${ }^{107}$

A comprehensive review in 2014 of empirical studies of the financial results of corporate responsibility by Gordon Clark, Andreas Feiner and Michael Viehs found that $90 \%$ of studies show that sound sustainability standards lower firms' cost of capital; $80 \%$ of studies show that the stock price performance of companies is positively influenced by good sustainability practices; and $88 \%$ of studies show that better E, S, or G practices result in better operational performance. ${ }^{108}$ While the answers are thus becoming clearer on the empirical questions related to the business case, it is not fully settled under what conditions corporate responsibility leads to better firm performance when it does, or the direction of causality. ${ }^{109}$ As Devinney put the question in 2009: What are the corporate responsibility competencies that can be linked to which specific performance outcomes, and through which operational and managerial competencies? ${ }^{110}$

\section{B. Board Composition and Committees}

\footnotetext{
${ }^{105}$ See id. at 482 .

${ }^{106}$ See id.

107 See id.

${ }^{108}$ See Gordon L. Clark, Andreas Feiner \& Michael Viehs, From the Stockholder to the Stakeholder: How Sustainability Can Drive Financial Outperformance (2015), available at http://papers.ssrn.com/sol3/papers.cfm?abstract_id=2508281. This report is an excellent resource because it analyzes the empirical literature on the financial effects of sustainability initiatives by type of initiative (E, S or G) and by various financial measures of interest (cost of debt capital; cost of equity capital; operating performance; and effect on stock prices). The study also separately identifies scientifically sound meta-studies and literature reviews. ${ }^{109}$ See Timothy M. Devinney, Is the Socially Responsible Corporation a Myth? The Good, the Bad and the Ugly of Corporate Social Responsibility, ACAD. MNGMT. PERSP. 44 (MAY 2009).

${ }^{110}$ See id. at 52-53.
} 
One structural feature that would seem to indicate a seriousness of purpose about corporate responsibility, or at least the potential for a connection between a governance mechanism and corporate social performance, would be a board committee dedicated to the topic. Yet the empirical evidence is mixed on this point. Judith Walls, Pascual Berrone and Philip Phan made the methodological observation that there are different aspects to a company's social performance, and so the mixed results from empirical studies could be a function of failing to untangle competing parameters. ${ }^{111}$ Moreover, the strategic use of disclosure to manage stakeholder relationships may obfuscate performance: the worst environmental performers might use the most environmental disclosure to manage public relationships, for instance, while the worst social performers (community, labor and supply chain management) might use the least social disclosure. ${ }^{112}$ Since disclosure was used as the evidence for corporate social performance in many previous studies, such patterns would produce conflicting—and inaccurate-- results. Thus, Walls et al. only evaluated environmental performance (not environmental disclosure) as a function of various aspects of governance (size of a company, board structure, ownership, executive power and executive compensation). ${ }^{113}$

The authors found two noteworthy effects regarding the board. First, the existence of a specialized environmental board committee was related to both better and worse environmental performance, suggesting that board committees could be established either to promote better environmental performance or as a reaction to environmental problems. ${ }^{114}$ Second, more independent, larger, and less diverse boards were associated with worse environmental

\footnotetext{
${ }^{111}$ See Judith A. Walls, Pascual Berrone \& Philip H. Phan, Corporate Governance and Environmental Performance: Is there Really a Link?, 33 STRAT. MNGMT. J. 885, 886 (2012).

${ }^{112}$ Indeed Mallin et al. found suggestions of this kind of strategic use of disclosure, while not exactly that pattern. See Christine A. Mallin, Giovanna Michelon \& Davide Raggi, Monitoring Intensity and Stakeholders' Orientation: How Does Governance Affect Social and Environmental Disclosure?, 114(1) J. OF BUS. ETHICS 29 (2013).

113 See Walls et al, supra note 111, at 886. Walls et al. used environmental performance data that has been collected by KLD.

${ }^{114}$ See id.
} 
outcomes, possibly because of a lack of in-depth knowledge of environmental risks to the company. ${ }^{115}$ Moreover, an important interaction Walls et al. describe is between a strong CEO (having both the role of CEO and Chairman of the Board) and an insider board: companies with this configuration have better environmental outcomes than do companies with a split CEO/Chair and more independent board. ${ }^{116}$ As Walls et al. state "This interesting finding suggests that powerful CEOs may be important for environmental outcomes, and that the vision of such CEOs can be fostered by boards consisting of supportive inside directors." ${ }^{\text {117 }}$ The same general pattern was demonstrated by Surroca and Tribò, who found that increased independence of the board, split CEO and Chair, and the presence of independent committees reduced corporate social performance. Surroca and Tribò interpreted these results to suggest that corporate responsibility is a strategy for management entrenchment and thus indicative of agency concerns. ${ }^{118}$ That is, by establishing stronger ties with internal and external constituents, particularly employees and community elites, the top management team insulates themselves from the accountability mechanisms of an independent board and Chair. ${ }^{119}$

That a dedicated corporate responsibility committee on the board cannot be taken as an unambiguous signal of support for the topic is suggested in Table 2, which lists the top 25 companies in the world, by market capitalization, and some features of their corporate governance and responsibility arrangements.

[Insert Table 2 here]

\footnotetext{
${ }^{115}$ See id. at 902.

${ }^{116}$ See id. at

${ }^{117}$ See id. at 902.

${ }^{118}$ See Jordi Surroca \& Josep A.Tribó, Managerial Entrenchment and Corporate Social Performance, 35 (5-6) J. OF BUS. Fin. \& ACCTNG., 748 (2008).

${ }^{119}$ See id. at 770.
} 
From this table we can see both corporate responsibility leaders with dedicated committees (Johnson \& Johnson; Novartis), as well as those companies in industries that have been subject to pointed social criticism (JPMorgan Chase, criticized for its role in the financial crisis; CocaCola for its role in water depletion in India and contributing to obesity generally through its products). Notable as well is that of the top 25 companies in the world, by market capitalization, 19 of which are from the United States, only one, Berkshire Hathaway, does not have a portion of its website dedicated to corporate responsibility or sustainability issues. Berkshire Hathaway may not need such a page, given that its CEO, Warren Buffett, is known for a clear commitment to simple guiding principles, such as this one prominently featured on the company's website:

Given the variety and complexity of ethical questions that may arise in the Company's course of business, this Code of Business Conduct and Ethics serves only as a rough guide. Confronted with ethically ambiguous situations, the Covered Parties should remember the Company's commitment to the highest ethical standards and seek advice from supervisors, managers or other appropriate personnel to ensure that all actions they take on behalf of the Company honor this commitment. When in doubt, remember Warren Buffett's rule of thumb:

“...I want employees to ask themselves whether they are willing to have any contemplated act appear the next day on the front page of their local paper - to be read by their spouses, children and friends- with the reporting done by an informed and critical reporter. ${ }^{120}$

But that even Alibaba, a Chinese internet sales company incorporated in the Cayman Islands which is being investigated for extensive sales of counterfeit products on its website, ${ }^{121}$ would include a "sustainability" page on its website suggests at least two things: global companies feel pressure from social actors to be seen to embrace positive social and environmental values; and companies' disclosure cannot be understood as an unambiguous signal of actual corporate responsibility.

\section{Patterns of Shareholder Ownership}

\footnotetext{
${ }^{120}$ See Berkshire Hathaway, Inc. Code of Business Conduct and Ethics, available at http://www.berkshirehathaway.com/govern/ethics.pdf. Unlike every other top company's website, Berkshire Hathaway's also has no pictures.

${ }^{121}$ See Scott Cendrowski, Nothing to See Here says Alibaba's Ma-and Customers Seem to Agree, available at http://www.fortune.com/2015/02/03/nothing-to-see-here-says-alibabas-ma-and-customers-seem-to-agree (quoting one "obsessive" Chinese customer that "of course" there are counterfeit goods being sold on Alibaba's Chinese website, but that there is a difference between "a fake Coach purse and tainted baby food.").
} 
As noted in the introduction to this chapter, there is evidence that some types of institutional shareholders are paying more attention to ESG issues, and this is one source of pressure on companies to also pay more attention. ${ }^{122}$ Trillions of dollars of invested capital supporting initiatives such as the U.N. Environment Program’s Principles of Responsible Investment or backing the Carbon Disclosure Project's efforts to get better data on company’s management of GHG emissions sends a signal to companies that at least some investors care about these topics. Of potentially greater significance, since 2009 Bloomberg has included 79 environmental and social data points in the information it sells to brokers and dealers throughout the world, as indicated in Table 3.

\section{[Insert Table 3 here]}

Following the logic of Robert Daines, Ian Gow and David Larcker, presumably Bloomberg would not be collecting, analyzing and selling this information if there was not a market for it. $^{123}$ Bloomberg has only sold these data since 2009, which gives further evidence of corporate responsibility as an emerging trend.

Richard Johnson and Daniel Greening have shown that the type of investors in a company has a significant effect on a company’s environmental and social performance. ${ }^{124}$ Firms with higher percentages of long term, pension fund investors had significantly better performance on social issues and environmental issues than firms with lower percentages, although the effect on

\footnotetext{
${ }^{122}$ See Ruth V. Aguilera, Deborah E. Rupp, Cynthia A. Williams \& Joyti Ganapathi, Putting the "S" Back in Corporate Social Responsibility: A Multi-Level Theory of Corporate Social Responsibility, 32:3 ACAD. OF MGMT. REV. 836 (2007)(discussing various motives for employees, managers, shareholders, customers, NGOs, and countries to pressure companies to adopt corporate responsibility initiatives, and theorizing about interactions among those entities and motives, and effects on the firm).

${ }^{123}$ See Robert M. Daines, Ian D. Gow \& David F. Larcker, Rating the Ratings: How Good are Corporate Governance Ratings, 98 J. FINAN. ECON. 439 (2010)(while finding the quality of corporate governance ratings to be suspect given little correlation among the ratings from different providers, the fact that these ratings agencies have a commercially-viable business shows that investors value the information).

${ }^{124}$ See Richard A. Johnson \& Daniel W. Greening, The Effects of Corporate Governance and Institutional Investor Types on Corporate Social Performance, 42:5 ACAD. MNGMT. J. 564 (1999)( using KLD data ).
} 
social issues was modest. ${ }^{125}$ Donald Neubaum and Shaker Zahra replicated these results in 2006, finding that large (1\% holdings) pension fund investors had a significant and positive effect on companies' social and environmental performance, particularly where funds coordinated their activism. Mutual fund and investment bank holdings had a significant and negative effect on corporate social performance, but only when these funds engaged in activism, not when they were simply passive investors. ${ }^{126}$ These findings have implications for corporate responsibility going forward, as short term shareholder activists become more visible, at least in the U.S. ${ }^{127}$. Moreover, these findings have broader social welfare implications given the emerging research discussed above that shows a long term management perspective fuels innovation. ${ }^{128}$

\section{Corporate Responsibility, Legal Origins and Corporate Governance Systems}

Consistent with what one might predict, empirical evidence shows that both country-level sustainability ratings and company-level corporate responsibility ratings are higher in countries with a stakeholder-oriented corporate governance system than in countries with a shareholderoriented corporate governance system. One quantitative study using MSCI (Morgan Stanley Capital, International) Intangible Value Assessment data, supplemented with specific social and environmental data from MSCI's Risk Metrics, found that:

"among different legal origins, the English common law—widely believed to be mostly shareholder oriented-fosters CSR the least; within the civil law countries, firms of countries with German legal origin outperform their French counterparts in terms of ecological and environmental policy, but the French legal origin firms outperform German legal origin

\footnotetext{
${ }^{125}$ See id.

${ }^{126}$ See Donald O. Neubaum \& Shaker A. Zahra, Institutional Ownership and Corporate Social Performance: the Moderating Effects of Investment Horizon, Activism, and Coordination, 32:1 J. MNGMT. 108 (2006)(using KLD data).

${ }^{127}$ See William W. Bratton \& Michael L. Wachter, Shareholders and Social Welfare, 36 SEATTLE L. REV. 489 (2013)(discussing shareholder activists and the corporate policies they promote).

${ }^{128}$ See text accompanying notes 93-105, supra.
} 
companies in social issues and labor relations. Companies under the Scandinavian legal origin score highest on CSR (and all its subfields). ${ }^{129}$

The authors of this study, Hao Liang and Luc Renneboog also find from the analysis of countrylevel sustainability ratings and financial development that countries with higher financial development (which tends to be those with shareholder-oriented corporate governance systems) have lower country-level sustainability ratings, including lower environmental responsibility ratings, and lower social responsibility and solidarity ratings. ${ }^{130}$ While the law and finance literature has emphasized the greater financialization of countries with a common-law legal origin, ${ }^{131}$ Liang and Renneboog's results suggest that financialization per se does not occupy the field of important social welfare outcomes.

A similar pattern for the importance of legal origins was found in another empirical study using a different data source (Innovest), but examining only differences between the Scandinavian legal system, the “civil and German” legal system, and the common law system (Great Britain and Ireland) within the EU. ${ }^{132}$ In that study Céline Gainet again found that Scandinavian countries outperformed those based on civil and German law with regard to

\footnotetext{
${ }^{129}$ See Hao Liang \& Luc Renneboog, The Foundations of Corporate Social Responsibility, Tilberg Law and Economics Center Discussion Paper No. 2013-023, available at http://ssrn.com/abstract=2371103. The MSCI Intangible Value Assessment (IVA) developed a series of 29 ESG scores from 1999 to 2011 using multiple sources of quantitative and qualitative data for the top 1,500 companies in the MSCI World Index, the top 25 companies in its emerging markets index, and the top 275 companies by market capitalization for the FTSE 100 and FTSE 250 and the ASX 200. Liang and Renneboog note that the governance factors within these 29 ESG scores account for less than $2 \%$ of the weight of the composite ESG score for a company, while the weight of the labor relations, industry specific risks in relation to carbon emissions, and environmental opportunity factors add up to $80 \%$. Id. at 8. Liang and Renneboog supplemented the MSCI IVA data with Risk Metrics data on environmental and social factors.

${ }^{130}$ See id. at 23.

${ }^{131}$ See Rafael la Porta, Florencio Lopez-de-Silanes \& Andrei Shleifer, The Economic Consequences of Legal Origins, 46 J. ECON. LiT. 285 (2008).

${ }^{132}$ See Gainet, supra note 4, at 212. Innovest uses quantitative and qualitative data evaluating 40 aspects of company action using 20 sources, attempting to capture actual company performance. Social metrics include governance of social issues, human capital measures, stakeholder capital measures, product and services evaluation, and relationships within emerging markets. For environmental measures, Innovest examines total EVA (economic value added) versus waste, and also five aspects of environmental risk and opportunities: historical liabilities, operating risk, sustainability and eco-efficiency risk, material risk, and strategic profit opportunities. Id. at 202.
} 
environmental performance, and that both outperformed countries in the EU with a common law origin. ${ }^{133}$ Gainet found the pattern with respect to social performance to be mixed (Scandinavian countries outperformed both civil and common law in one year, but the common law countries in Europe, Great Britain and Ireland, outperformed the civil law countries in two years.) These mixed results may have been due to the short time frame (2004 to 2007) over which the social performance of the companies was being examined, given data availability, or they demonstrate convergence in labor protections at the EU level, as Gainet suggests. ${ }^{134}$

These studies give evidence of an important vector by which law structures the corporate social relationship, the legal origins vector, which shapes, among other things, a country's views on the proper role of the state in the economy. Where, as in the common law system, the state's role in the economy is understood to be more limited in addressing economic inequality or promoting and protecting labor or environmental interests than among Scandinavian countries or those based on civil law legal families, there is more pressure for voluntary corporate responsibility initiatives to address these issues, as Matten and Moon have argued. ${ }^{135}$ The above evidence suggests those voluntary initiatives are less effective in promoting social and environmental social welfare than are the types of laws and institutional arrangements found in the Scandinavian and civil law legal contexts.

\section{IMPLICATIONS AND ANALYSIS}

Whether attention to corporate responsibility does lead to financial outperformance in some cases, and what those cases are, does not settle the "case of corporate responsibility," for there is a much deeper disagreement with which this chapter concludes. That is the perennial, one might

\footnotetext{
${ }^{133}$ See id.

${ }^{134}$ See id. at 213.

${ }^{135}$ See id. at 49.
} 
say religious, ${ }^{136}$ debate over the purpose of the firm. Is it "simply" to produce products and services that create economic rents to be distributed to rights' holders according to pre-existing contractual, statutory and (possibly) normative obligations? (Given that close to $70 \%$ of new companies ultimately fail, that task cannot be taken as too simple. $)^{137}$ Or does the firm also have a social obligation to minimize harm to people and the natural environment in its pursuits of profits, or even a positive duty to promote social welfare beyond its creation of economic rents? In corporate governance and law, this debate tracks the competition between a shareholder versus stakeholder view of directors' and officers' fiduciary obligations. The literature on each side of this debate is so extensive that the following will simply sketch out aspects of the various positions that have direct implications for differing views regarding corporate responsibility, and then give some indications of why it might be possible, and important, to narrow the gap between these seemingly irreconcilable positions.

\section{A. Shareholder Primacy}

Milton Friedman's articulation of firms' responsibilities is the iconic expression of a predominantly economic perspective on the nature of the firm:

There is one and only one social responsibility of business - to use its resources and engage in activities designed to increase profits so long as it stays within the rules of the game, which is to say, engages in open and free competition without deception or fraud. ${ }^{138}$

This statement was part of a New York Times article in which Friedman contributed to a vigorous debate that was then on-going within the business community. Some academics and members of the business community in the U.S. had begun to argue that companies had responsibilities to

\footnotetext{
${ }^{136}$ See id. at 44

${ }^{137}$ See Startup Failure Rate by Industry, available at http://www.statisticbrain.com/startup-failure-by-industry.

${ }^{138}$ See Milton Friedman, The Social Responsibility of Business is to Increase its Profits, N.Y.TIMES MAGAZINE 6 (Sept. 13, 1970).
} 
respond to civil rights and anti-war unrest, as well as strategic interests in providing an attractive alternative to collectivist social movements like Marxism, socialism and organized labor, by paying greater attention to making a positive social contribution. ${ }^{139}$ Friedman and others taking his view responded that the social contribution firms make from running a profitable business, employing people, paying taxes and distributing some part of net profits to shareholders is the business firm's positive social contribution. A concern that later writers in this vein articulated is that trying to create additional social benefits beyond those that flow from honest profit-making within the confines of law will dilute management's focus, undermine economic performance, and thereby ultimately undermine social welfare. ${ }^{140}$

A number of arguments for a narrow view of managers and directors obligations devolve from shareholders' special position in the firm. One theoretical perspective, the contractarian view of the corporation as articulated by Steve Bainbridge (among others), asserts that an implicit term of the contract between shareholders and the firm is that the directors and managers will act in the shareholders’ best interests, understood as maximizing their wealth. ${ }^{141} \mathrm{~A}$ pragmatic perspective suggests that given the broad discretion directors and top managers have to run the firm, and given that in shareholder-oriented corporate governance systems only

\footnotetext{
${ }^{139}$ See id. (e.g., note Friedman's statement that “[t]he businessmen believe that they are defending free enterprise when they declaim that business is not concerned "merely" with profit but also with promoting desirable "social" ends; ... In fact they are-or would be if they or anyone else took them seriously-preaching pure and unadulterated socialism. Businessmen who talk this way are unwitting puppets of the intellectual forces that have been undermining the basis of a free society these past decades."). See Davis, supra note 1, for a delineation of the perspectives in that historical debate.

${ }^{140}$ See Henry Hansmann \& Reinier Kraakman, The End of History for Corporate Law, 89 GEO. L. J. 439, 442-443 (2001) (writing that "[t]he point it simply that now, as a consequence of both logic and experience, there is convergence on a consensus that the best means to this end - the pursuit of aggregate social welfare-is to make corporate managers strongly accountable to shareholder interests and (at least in direct terms) only to those interests.”).

${ }^{141}$ See Stephen M. Bainbridge, Director Primacy: The Means and Ends of Corporate Governance, 97 Nw. U. L. REV. 547 (2003). There are other theoretical arguments for shareholder primacy, such as those based on a concept of shareholders as principals and managers and directors as agents in an agency relationship. For a critical summary of this view see Bratton \& Wachter, supra note 127.
} 
shareholders' have direct rights to vote or to sue, ${ }^{142}$ it is not surprising that firms and their managers will act in shareholders' interests in order to avoid being sued, voted out of office, or thrown out of office in a hostile take-over, as recently argued by Leo Strine, Jr., the Chief Justice of the Delaware Supreme Court. ${ }^{143}$ In another recent article, CJ Strine argues that acting in shareholders' interests is not only pragmatic but legally required and so corporate responsibility could be a breach of fiduciary duty. ${ }^{144}$ This argument will be discussed in more detail below.

From the shareholder-oriented perspective, corporate responsibility is too much responsibility to impose on directors. Advancing social policy goals is the job of government, not business. ${ }^{145}$ In contrast, directors are elected by the shareholders to run the firm in the shareholders' interests. Balancing other constituents interests' by making “tradeoffs between the welfare of shareholders and that of non-shareholder constituencies»146 is problematic because it is inconsistent with the proper exercise of directors' power to advance shareholders' interests,

\footnotetext{
${ }^{142}$ While Canada is often included as a country having a shareholder-oriented corporate governance system, that is no longer correct. Canada permits non-shareholder constituents to bring derivative actions (sue) by statute, and the Supreme Court of Canada has twice articulated a stakeholder perspective on the firm and directors' obligations. See Peoples Department Stores Inc. (Trustee of) v. Wise, 2004 SCC 68, [2004] 3 S.C.R. 461 (stating at [42] that "[w]e accept as an accurate statement of law that in determining whether they are acting with a view to the best interests of the corporation it may be legitimate, given all the circumstances of a given case, for the board of directors to consider, inter alia, the interests of shareholders, employees, suppliers, creditors, consumers, governments and the environment."); BCE Inc. v. 1976 Debentureholders, 2008 SCC 69, [2008] 3 S.C.R 560( stating at [ ] that "the question is whether, in all the circumstances, the directors acted in the best interests of the corporation, having regard to all relevant considerations, including, but not confined to, the need to treat affected stakeholders in a fair manner, commensurate with the corporation's duties as a responsible corporate citizen.).

${ }^{143}$ See Leo E. Strine, Jr., Making it Easier for Directors to "Do the Right Thing”?, 4 HARV. BUS. L. REV. 235 (2014), available at http://papers.ssrn.com/sol3/papers.cfm?abstract_id=2539098.

${ }^{144}$ See Leo E. Strine, Jr., The Dangers of Denial: The Need for a Clear-Eyed Understanding of the Power and Accountability Structure Established by the Delaware General Corporation Law, ("Dangers of Denial”), University of Pennsylvania Law School Institute for Law and Economics Research Paper no. 15-08, available at http://ssrn.com/abstract=2576389.

${ }^{145}$ See, e.g., David L. Engel, An Approach to Corporate Social Responsibility, 32 STAN. L. REV. 1 (1979)(directors are not well suited to balance competing social policy interests, which is the job of legislators); Daniel R. Fischel, The Corporate Governance Movement, 35 VAND. L. REV. 1259 (1982)(redress for those concerned about a lack of corporate social accountability is through the political process, not through disrupting the "voluntary arrangements that private parties have entered into in forming corporations.”).

${ }^{146}$ Stephen M. Bainbridge, Corporate Social Responsibility in the Night-Watchman State, 115 CoL. L. REV. SIDEBAR 39, 49 (2015) (briefly summarizing his prior work discussing this concern).
} 
and because it risks undermining accountability by allowing directors to act in their own selfinterest while claiming to act in other constituents' interests. ${ }^{147}$

Given this perspective, the importance of the business case is obvious. If corporate responsibility initiatives do not make money for the firm, they fail. While many other business strategies can also fail, such as mergers and acquisitions, where half to two-thirds do not make money for the acquiring firm and resulting entity, ${ }^{148}$ mergers and acquisitions at least aim to make money for the firm, and so their legitimacy as a business strategy is not in doubt. Corporate responsibility initiatives do not have that legitimacy of motivation, from the critics' perspective (although "strategic corporate responsibility" is intended to be profitable, ${ }^{149}$ and many responsibility initiatives are profitable, as discussed above). ${ }^{150}$ As a result, in this view, corporate responsibility is too strong a concept: it risks economic underperformance, it usurps government's policy roles, and it is beyond the boundaries of directors' and managers' legitimate exercise of power by seeking to advance non-shareholder interests.

\section{B. Stakeholder Theory}

In contrast, to many academic critics of corporate responsibility, it is still too weak a concept. There are a number of strands to this thinking, as with the shareholder perspective. One is stakeholder theory, which is the major theoretical competitor to shareholder primacy. Stakeholder theory is generally attributed to Ed Freeman, ${ }^{151}$ although he attributes the idea to "a very old tradition that sees business as an integral part of society rather than an institution

\footnotetext{
${ }^{147}$ See id.

${ }^{148}$ See Robert F. Bruner, DeAls From Hell: M\&A Lessons that Rise AbOve the Ashes Ch.1 (2005).

${ }^{149}$ See Porter and Kramer, supra note 23, and McWilliams \& Siegel, supra note 24, for examples of strategic corporate responsibility.

150 See text accompany notes 84-108, supra.

${ }^{151}$ See R. Edward Freeman, The Politics of Stakeholder Theory, 4 BUS. ETHICs Q. 409 (1994).
} 
separate and purely economic in nature." ${ }^{\text {152 }}$ From the perspective of stakeholder theory, economic value is created by voluntary relationships among many parties who cooperate to create successful businesses. It is an ethical theory about the values of management in relationships with those parties, and also a management theory about how to create and manage successful companies. As Freeman states, “[c]apitalism works because entrepreneurs and managers put together and sustain deals or relationships among customers, suppliers, employees, financiers, and communities.” ${ }^{153}$ This theory does not deny that shareholders are important stakeholders in the firm, but does reject the view that shareholders' interests are the only interests that managers and directors should consider in managing a successful firm. ${ }^{154}$

From a stakeholder perspective, successful companies incorporate and rely upon multiple social and natural inputs, such as an educated work-force, the physical infrastructure for the production, transportation and distribution of goods, an effective legal system, and natural capital inputs of water, air, commodities, and so forth. Since some significant portion of the inputs of corporate success, including financial inputs, have been contributed by parties other than shareholders, those parties also have interests to be considered in determining the responsibilities of managers and directors and in distributing the outputs of corporate action. Some, perhaps many, of those interests will be protected by contractual or regulatory arrangements, but others cannot be specified ex ante, and so must depend on corporate participants to fairly balance

\footnotetext{
${ }^{152}$ R. Edward Freeman \& Jeanne Liedtka, Stakeholder Capitalism and the Value Chain, 15 EUR. MNGMT. J. 286, 286 (1997). Freeman and Liedtka attribute stakeholder theory to other writers in management in the 1960s, including Eric Rhenman, Igor Ansoff, and Russell Ackoff.

${ }^{153} I d$. at 287.

${ }^{154} \mathrm{Id}$.
} 
multiple parties’ legitimate claims ex post, as in Margaret Blair and Lynn Stout’s team production theory of corporate law. ${ }^{155}$

To some stakeholder theorists, corporate responsibility is too modest, given its emphasis on disclosure and voluntarism. Some serious, even extreme, human rights problems persist despite corporate responsibility initiatives and expanded ESG disclosure. Andy Crane has shown that “modern slavery” (traditional slavery, bonded labor, human trafficking and forced labor) is endemic in some industries (agriculture, mining, extraction, construction, brickmaking, carpet weaving, domestic work and sex work); global estimates range from 12 million to 30 million people enslaved throughout the world. ${ }^{156}$ The limits of corporate responsibility can be seen in the problem of slavery in the West African cocoa industry. That problem was widely publicized by NGOs, putting pressure on multi-national companies to sign the Harkin/Engel Cocoa Protocol in 2001, which specifically directed the industry to self-regulate. ${ }^{157}$ According to Crane, that Protocol has led to "pilot programs” to determine the most effective ways to eliminate the slavery, and “a mooted, but much delayed, program for monitoring and enforcement.”158 In other words, fourteen years later the problem has not been solved by industry initiatives. Tragic evidence of the insufficiency of long-established voluntary company codes of conduct and industry responsibility initiatives continues to accumulate. The Rana Plaza collapse in Bangladesh in 2013, which killed 1,134 people producing clothes for 29 global clothing companies, ${ }^{159}$ or Barrick Gold’s settlement of claims in 2015 that its security personnel had raped

\footnotetext{
155 Margaret M. Blair \& Lynn A. Stout, A Team Production Theory of Corporate Law, 85 VA. L. REV. 248 (2003).

${ }^{156}$ Andrew Crane, Modern Slavery as a Management Practice: Exploring the Conditions and Capabilities for Human Exploitation,38 ACAD. MNGMT. REV. 49 (2013) (citing the ILO and academic studies).

${ }^{157}$ See id. at 58.

${ }^{158} \mathrm{Id}$.

${ }^{159}$ See Clean Clothes Campaign, Compensation is Long Overdue, available at http://www.cleanclothes.org/ranaplaza.
} 
137 women in Papua New Guinea over a period of decades, show some limits to the reach of the voluntary approach.

Moreover, the "business case” may never be strong enough to overcome the economic disincentives to invest in higher labor costs or expensive pollution abatement without a supportive regulatory framework that creates a level playing field for competition. Many of the business drivers of corporate responsibility depend on consumers being willing to pay more for goods produced in socially-responsible fashion, employees being selective about where they will work, choosing only the most responsible employers, and investors generally investing and disinvesting based on social parameters. ${ }^{160}$ Jan Wouters and Leen Chanet bring both a moral and a pragmatic argument to show the limits of each aspect of this business case. ${ }^{161}$ As a matter of morality they argue that the business case is a means to the end of responsible business conduct, not an end in itself, and should be evaluated as such: "[I]f respect for human rights is fundamental to our society, whether or not ensuring such respect would bring economic advantages is irrelevant; achieving it remains our final goal.” ${ }^{\text {"162 }}$ From a pragmatic perspective, neither the ethical consumer movement nor socially-responsible investor pressure are strong enough to make a demonstrable contribution to the business case without a supportive regulatory environment, in their view, such as by requiring fair trade labeling of products at the point of purchase, or requiring consistent, comparable ESG disclosure by public companies. ${ }^{163}$ Olivier DeSchutter also argues for the importance of a supportive regulatory framework. ${ }^{164}$ Using an environmental example, he states "for a government, the most direct solution to [advance]

\footnotetext{
${ }^{160}$ See Aguilera et al., supra note 122, for discussions of each of these factors as drivers for companies adopting corporate responsibility initiatives.

${ }^{161}$ See Jan Wouters and Leen Chanet, Corporate Human Rights Responsibility: A European Perspective, 6 Nw. J. INT’L H. RTS. 262 (2008).

${ }^{162} I d$. at 267.

${ }^{163}$ See id. at 267-270.

${ }^{164}$ See Olivier DeSchutter, Corporate Social Responsibility European Style, 14 EUR. L. J. 203 (2008).
} 
environmentally responsible conduct is simply to let the price of energy go up, to collect high fees for waste disposal (calculated according to volume) and to oblige companies to internalise the costs of the pollution they create. There would simply be no ground on which to build the business case for CSR, if we bracket these public interventions away.”165

Whether the voluntary "business case" is stronger than these assessments suggest may depend on the reputational benefits and risks of corporate responsibility or irresponsibility, and the role of the media in amplifying those benefits or risks. Estimates indicate that $70 \%$ to $80 \%$ of a company’s market value today is based on "intangibles" such as brand reputation, intellectual capital and goodwill. ${ }^{166}$ High-profile tragedies such as the Rana Plaza collapse or the Deepwater Horizon explosion cause industry-wide reputational harm and societal (and investor) pressures for redress. ${ }^{167}$ As BP found out after the Deepwater Horizon explosion, a gap between a company's reputation and the company's actual performance creates the potential for “reputational risk,” which may amplify the effects of media coverage of responsibility issues. ${ }^{168}$ Apple is an interesting counter-example here, however. While its reputation may have suffered somewhat from a series of critical media coverage in 2010 concerning the harsh conditions under which Apple products are produced in China, ${ }^{169}$ that negative media coverage has not dented

\footnotetext{
${ }^{165}$ Id. at 221.

${ }^{166}$ See Robet G. Eccles, Scott C. Newquist, \& Roland Schatz, Reputation and its Risks, HARV. Bus. REV. (Feb. 2007), available at https://hbr.org/2007/02/reputation-and-its-risks.

167 See Clark, Feiner \& Viehs, supra note 108, at 14, indicating that after the Deepwater Horizon tragedy BP stock lost $50 \%$ of its value, and the oil majors generally lost $18.5 \%$. Five years later, BP's share price is still underperforming its peer group by about 37\%. See id.

${ }^{168}$ See Eccles et al., supra note 166, discussing how BP’s “Beyond Petroleum” public relations campaign and widely-reported research projects on solar power led to greater disillusion among consumers after the Deepwater Horizon explosion.

${ }^{169}$ See Richard Bilton, Apple Failing to Protect Chinese Factory Workers, BBC Panorama (Dec. 18, 2014), describing a BBC Documentary airing in December, 2014, in which a number of BBC reporters got jobs in a Foxconn factory working on Apple products, and reported on conditions of their work and lives there.
} 
Apple's position as the world's largest company by market capitalization. ${ }^{170}$ This disconnect between media coverage of a social responsibility issue and consumer reactions was encapsulated brilliantly in the title of an article that empirically studied the limits of the business case, at least insofar as it depended on ethical consumption: "Sweatshop Labor is Wrong Unless the Shoes are Cute.”171

Another criticism builds on assertions about the strategic use of the business case as an argument for voluntary corporate responsibility rather than regulatory intervention. From this perspective corporate responsibility is a business strategy employed specifically to resist regulation, thus undermining the ability of society to cause companies to limit and then internalize negative externalities. Ronen Shamir has argued that companies have "constructed” the field of corporate responsibility through teaching in business schools, through lobbying, and through litigation, as “an essentially voluntary and non-enforceable domain” in order to "resist the legalization of their social duties.”"172 He has also argued that "through a set of social events, workshops and public ceremonies," businesses "shape notions such as “social responsibility" and "social change” in ways that are amenable to business and employers' concerns,” thus “preventing the use of law as a means for bringing greater social responsibility.”173 His interpretation is supported by an historical analysis by Rami Kaplan, in

\footnotetext{
${ }^{170}$ See Table 2, supra, showing Apple’s market capitalization at $\$ 752$ billion as of March, 2014, twice as large as the next largest company, Exxon Mobil (\$369 billion).

${ }^{171}$ See Neeru Paharia, Kathleen Vohs, \& Rohit Deshpandé, Sweatshop Labor is Wrong Unless the Shoes are Cute: Cognition Can Both Help and Hurt Moral Motivated Reasoning, 121 Org. BeHAV. \& HuMAN DeCision Processes 81 (2013).

${ }^{172}$ See Ronen Shamir, Between Self-Regulation and the Alien Tort Claims Act: On the Contested Concept of Corporate Social Responsibility, 38 LAW \& SOC’Y REV. 635 (2004).

${ }^{173}$ Shamir, supra note 14, at 676.
} 
which Kaplan argues that “corporate responsibility was devised [in the 1950’s] by the corporate capitalist elite, broadly defined, as an instrument for pre-empting governmental intervention.”174

Thus, from both the stakeholder and the sociological perspective corporate responsibility is too weak, and yet too strong. It is an insufficient constraint on how companies do business in a world of accelerating pressures on natural capital and ill-distributed opportunities for human flourishing. Yet, at the same time it is effectively undermining the conditions for putting more substantive regulation in place.

\section{Evaluating the Arguments}

By 2015, the argument that corporate responsibility requires companies and the board to take on an essentially political role for which they are ill-suited rings hollow, given the extensive involvement of American companies in law-making, lobbying, litigation to narrow regulation, and constitutionally-protected electoral politics. ${ }^{175}$ But two arguments for shareholder primacy that are advanced in the U.S. law literature remain important to address: the idea that balancing multiple stakeholders' interests will undermine accountability and allow directors and managers too much discretion to act in their own self-interest; and the argument that it is legally required for boards and managers to act in the interests of shareholders, and shareholders only, such that corporate responsibility initiatives could be a breach of fiduciary duty. This Author will address

\footnotetext{
${ }^{174}$ See Rami Kaplan, "Who has been regulating whom, business or society? The mid-20 $0^{\text {th }}$-century institutionalization of 'corporate responsibility,' SOCIO-ECONOMIC REV. 1 (2014).

${ }^{175}$ See Cynthia A. Williams and John M. Conley, Trends in the Social [Ir] responsibility of American Multinational Corporations: Increased Power, Diminished Accountability, 25 FORDHAM ENVIR. L. REV. 46 (2013)(discussing these trends, and including discussions of Citizens United v. Federal Election Comm’n., 558 U.S. 310 (2010), which expanded corporations' and unions' First Amendment rights regarding electoral participation, and Royal Dutch Shell v. Kiobel, 133 S. Ct. 1659 (2013), which narrowed the potential Alien Torts Claims Act accountability of multinational corporations).
} 
the second argument first, because if shareholder primacy is required by law, that ends the discussion, at least in the United States.

Two points that are relevant to both issues are given insufficient attention in the law literature, though, and so will be highlighted in advance. First, the data do not support the view that corporate responsibility initiatives inevitably cause financial losses; in fact, to the contrary. In an overwhelming majority of cases there is no trade-off between a company's financial health and actions that arise from a broad concept of social obligation, as the studies evaluated by Clark, Feiner, and Viehs show. ${ }^{176}$ The management literature is much more sophisticated on this point than is the law literature. Second, many of the arguments in the law literature against corporate responsibility ignore what large companies are saying they are doing, around the world. As set out above, 93\% of the world's largest companies discuss their environmental and social initiatives, many in great detail, and many including substantiated, audited data about the effects of those initiatives. ${ }^{177}$ Unless one considers everything that a company says about its social responsibilities to be unsubstantiated public relations, then it should be incumbent upon judges and law professors who write about these matters to consider these facts in their analyses.

\section{Shareholder versus stakeholder theory}

The proper understanding of the implications of corporate boards' legal obligations for issues of corporate responsibility has become a matter of vigorous debate again in the United States, inspired by Prof. Lynn Stout's short, sharply-critical book, written for a popular audience, entitled “The Shareholder Value Myth: How Putting Shareholders First Harms Investors,

\footnotetext{
${ }^{176}$ See text accompanying notes 84-108, supra. See also Clark, Feiner and Viehs, supra note 108.

${ }^{177}$ See text accompany note s 5-6, supra.
} 
Corporations and the Public.”" ${ }^{178}$ That book has inspired multiple, equally critical reactions by respected scholars, ${ }^{179}$ including a number from CJ Strine. ${ }^{180}$ CJ Strine recognizes that "directors are generally empowered to manage the corporation in a way that is not dictated by what will best maximize the corporation’s current stock price,”181 but argues that “advocates for corporate social responsibility" make a more fundamental claim, and "pretend that directors do not have to make stockholder welfare the sole end of corporate governance within the limits of their legal discretion." "182 He rejects the argument of "these well-meaning commentators" that "the business judgment rule is cloaking a system of law giving directors the ability to act for any reason they deem appropriate.” ${ }^{183}$ Evaluating the arguments in this debate can provide the context for a number of observations regarding shareholder primacy, stakeholder theory, and corporate responsibility.

First, it is inaccurate to argue that shareholders have no special place in corporate law in Delaware and in the United States generally. They clearly do. Shareholders are the only group entitled to vote for the board and to approve important corporate transactions, although creditors can also exert control rights through their contracts; shareholders are the only group with rights to bring suit derivatively on behalf of the corporation; and the board's fiduciary duties run "to the

\footnotetext{
${ }^{178}$ LYNN STOUT, THE SHAREHOLDER VALUE MYth: HOW PUTTING SHAREHOLDERS FirST HARMS INVESTORS, CORPORATIONS, AND THE PUBliC (2010). Professor Stout has been a prolific critic of shareholder primacy in the law literature from economic and legal perspectives, but it is her short popular book that seems to have inspired this iteration of the corporate responsibility debate. See, e.g. Lynn A. Stout, The Toxic Side Effects of Shareholder Primacy, 161 U. PENN. L. REV. 2003 (2013); Blair \& Stout, supra note 155 (the team production theory of boards' responsibilities).

${ }^{179}$ See, e.g, Jonathan Macey, Sublime Myths: An Essay in Honor of the Shareholder Value Myth and the Tooth Fairy, 91 TEX. L. REV. 911 (2013) (critically reviewing The Shareholder Value Myth).

${ }^{180}$ See Strine, supra notes 143 and 144.

${ }^{181}$ Strine, Dangers of Denial, supra note 144, at 4.

${ }^{182} I d$. at 3.

${ }^{183} I d$. at 7.
} 
corporation and its shareholders.” ${ }^{184}$ These legal rights matter and should not be treated as unimportant, as Prof. Stout's arguments can sometimes seem to do.

Yet, as just stated, the Delaware Supreme Court has in a number of cases articulated the fiduciary duties of directors as advancing the interests of "the corporation and its shareholders." When these interests conflict, the Court has upheld board actions that frustrate shareholders’ short-term financial interests in favor of the board's well-considered views about the company's longer-term strategies and prospects (as CJ Strine recognizes but does not discuss in any detail). ${ }^{185}$ In Paramount Communications v. Time, the Delaware Supreme Court upheld the directors' power to reject the shareholders' views and take defensive measures against a wellabove-market tender offer. ${ }^{186}$ While it might be argued that this simply reflects the authority structure of Delaware corporate law, since it is the directors and not the shareholders who have the statutory power to manage the company, ${ }^{187}$ the Time board's actions were demonstrably not shareholder wealth maximizing. If fiduciary principles required shareholder wealth maximizing in general, the directors' actions in Paramount v. Time would not have been upheld.

There is one circumstance where shareholders' wealth must be maximized, and that is where the shareholders are being cashed out, as in Revlon, Inc. v. MacAndrews \& Forbes Holdings, Inc. ${ }^{188}$ In that circumstance, "the duty of the board . . change[s] from the preservation

\footnotetext{
${ }^{184}$ See Unocal Corp. v. Mesa Petroleum Co., 493 A.2d 946 (Del. 1985)(board's obligation is to act in "the best interests of the corporation and its shareholders”); Paramount Communications v. Time, 571 A.2d 1140 (Del. 1989)(same).

${ }^{185}$ See id. at 4 (stating that "To the extent that these commentators argue that directors are generally empowered to manage the corporation in a way that is not dictated by what will best maximize the corporation's current stock price, they are correct," citing Paramount Communications, Inc. v. Time, 571 A.2d 1140, 1154 (Del. 1989) and Air Products and Chemicals, Inc. v. Airgas, Inc., 16 A.3d 48, 112 (Del. Ch. 2011).).

${ }^{186}$ Paramount Communications, Inc. v. Time, 571 A.2d 1140, 1154 (Del. 1989).

${ }^{187}$ As Bob Joffe, the Cravath lawyer who represented Time in the oral argument before the Delaware Supreme Court, put the point, "Your Honor, Delaware law does not require that every important corporate decision be put to a shareholder plebiscite or referendum."

${ }^{188} 506$ A.2d 173 (Del. 1986).
} 
[of the company] as a corporate entity to the maximization of the company's value at a sale for the stockholders' benefit." ${ }^{\prime 89}$ Revlon duties have also been found where the control structure of a company is being changed, such as where a publicly-held company with dispersed shareholders is being pursued by a company with a controlling shareholder, and will become a controlled company if the transaction goes forward. Paramount v. QVC was such a case. ${ }^{190}$ But these are the only circumstances where the board's obligation is to maximize share value, according to the Delaware Supreme Court. Moreover, shareholder pressure cannot put a company into Revlon mode; that determination is reserved to the board. ${ }^{191}$

A former Chief Justice of the Delaware Supreme Court, Norman Veasey, has interpreted these precedents as follows:

[I]t is important to keep in mind the precise content of this "best interests" [of the corporate entity] concept - that is, to whom this duty is owed and when. Naturally, one often thinks that directors owe this duty to both the corporation and the stockholders. That formulation is harmless in most instances because of the confluence of interests, in that what is good for the corporate entity is usually derivatively good for the stockholders. There are times, of course, when the focus is directly on the interests of stockholders [citing Revlon and Paramount Comms. v. QVC]. But, in general, the directors owe fiduciary duties to the corporation, not to the stockholders." 192

Moreover, as Prof. Stout and others emphasize, the protection of the business judgment rule allows directors to make decisions that are in the longer-term interests of the corporation, such as investing in research and development, building new plants, or paying employees well, notwithstanding some shareholders who would rather have the company's money spent on

\footnotetext{
${ }^{189} \mathrm{Id}$. at 182.

${ }^{190} 637$ A.2d 34 (Del. 1994)(holding that Revlon duties are triggered by a change in control or a break-up of the company).

${ }^{191}$ Chancellor Chandler made this point in discussing the evolution of the Paramount standard in Air Products and Chemicals, Inc. v. Airgas, Inc., 16 A.3d 48, 102 (Del. Ch. 2011).

${ }^{192}$ E. Norman Veasey \& Christine T. DiGuglielmo, What Happened in Delaware Corporate Law and Governance from 1992-2004? A Retrospective on Some Key Developments, 153 U. Penn. L. Rev. 1399, 1431 (2005).
} 
them. ${ }^{193}$ As a practical matter, there is going to be no liability for a board that frustrates some

shareholders' short-term interests and decides to pay its employees more than the minimum

wage, for instance, or reduces the prices its products could be sold for so that more employees

can buy the product - the latter of which the board of the Ford Motor Company did in 1915, which decision was upheld by the Michigan Supreme Court in Dodge v. Ford, ${ }^{194}$ and the former

as Walmart just did in 2015. ${ }^{195}$ This argument about the business judgment rule frustrates CJ

Strine and Prof. Bainbridge, among others, but Prof. Stout (and others) are correct that this is

\begin{abstract}
${ }^{193}$ See Stout, supra note 178, at 2, 24-46. Other scholars have made this argument about the power of the business judgment rule as well. See, e.g.,Lynne Dallas, The New Managerialism and Diversity on Corporate Boards of Directors, 76 TUL. L. REV. 1363 (2002); Einer Elhauge, Sacrificing Corporate Profits in the Public Interest, 80 N.Y.U. L. Rev. 733, 770-772 (2005).

${ }^{194}$ In Dodge v. Ford, 204 Mich. 459, 170 N.W. 668 (1919), the Michigan Supreme Court stated that "there should be no confusion (of which there is evidence) of the duties which Mr. Ford conceives that he and the stockholders owe to the general public and the duties which in law he and his co-directors owe to protesting, minority stockholders. A business corporation is organized and carried on primarily for the profit of the stockholders.” 170 N.W. at 683. This is the oft-quoted language from this opinion. It is, however, dicta. What is often not discussed is that the Michigan Supreme Court refused to enjoin the Ford Motor Company’s plans to increase production and reduce the cost of its cars, in part so that more of its employees could buy the cars. The Dodge Brothers had argued that Henry Ford wanted to expand production and cut costs "not for the good of the company but to give more employment” and to allow more people to buy the cars. Id. at 678. Because of the business judgment rule, the Court refused to find that Henry Ford's plan was legally impermissible, and so it did not enjoin the company's actions, as had been requested., stating that”[t] he judges are not business experts.” Id. at 684. It did order a higher dividend to be paid because it found that the company could expand production, cut the costs of cars, and engage in some of its plans for vertical integration and still have substantial assets available from which to pay dividends. Thus, the opinion can support either CJ Stine or Prof. Stout's views. That is, there is great latitude for company directors to act to promote the welfare of their employees, the communities in which they operate, their customers and suppliers, or even the environment (Stout's view), but only so long as there is a plausible justification for how that advances the company's long-term financial well-being (Strine's view).

${ }^{195}$ See Doug McMillon, CEO Walmart, In Letter to Associates Walmart CEO Doug McMillon Announces Higher Pay, Feb. 19, 2015, available at http://blog.walmart.com/in-letter-to-associates-walmart-ceo-doug-mcmillonannounces-higher-pay. In the letter, McMillon states that “today, we're announcing a series of important changes that demonstrate our commitment to you, our associates” because the CEO concluded that "it's clear to me that one of our highest priorities must be to invest more in our people this year.” There is no discussion of this decision being anything other than employee-focused. CJ Strine might consider this a "confession case," and by his logic, "if a fiduciary admits that he is treating an interest other than stockholder wealth as an end in itself, rather than an instrument to stockholder wealth, he is committing breach of fiduciary duty." Strine, Dangers of Denial, supra note 144, at 20. It is unlikely that the shareholders of Walmart would prevail in a suit based on that theory, though, given the business judgment rule, and given the likely positive effects of a decision like this one on employees' “citizenship behavior,” which presumably translates into positive financial outcomes. See Russell Cropanzano, Deborah Rupp, Carolyn Mohler, \& Marshall Schminke, Three Roads to Organizational Justice’, in 20 RESEARCH PERSONnEl AND HumAn ResourCes MGMT. 1 - 113 (2001)(discussing three decades of literature in organizational psychology showing that employees who perceive that they are being treated fairly are more productive, more engaged in the company, have lower absentee rates and stay longer in the job).
\end{abstract}


how the law operates. ${ }^{196}$ CJ Strine is undoubtedly correct that there could be problems if a board makes a social or environmental decision where there is no conceivable long-term benefit to the company and thus the shareholders, but in today's world it is hard to imagine what such a decision would be, given social expectations that companies will be responsible citizens and the reputational implications of frustrating those expectations. It is much more likely that a managerialist decision would create problems, such as a company giving a retiring $\mathrm{CEO}$ an apartment in New York, maid service and fresh flowers for life, which raises duty of loyalty concerns not implicated by corporate responsibility. ${ }^{197}$

Thus, the law—at least as decided by the Delaware Supreme Court—does not yet require shareholder wealth maximizing as the standard of conduct in order for boards to meet their fiduciary obligations, except in the circumstances described as being in "Revlon mode." Consistent with CJ Veasey's view, we can conclude that shareholders are important beneficiaries of fiduciary obligations in Delaware, of course, but only so long as their interests and the corporation’s long-term interests are in harmony. Corporate responsibility initiatives are one type of strategy to promote the corporation’s long-term financial well-being, as the empirical evidence shows, and thus there is no fiduciary breach.

But, even if lawful, is a multi-stakeholder focus going to mask officers' and directors’ self-interest, and thereby undermine accountability, as has been argued? ${ }^{198}$ Both on the question of self-interest, and on accountability, the prioritizing of shareholders' interests as it has been

\footnotetext{
${ }^{196}$ See Strine, Dangers of Denial, supra note 144, at fn. 72, discussing Bainbridge view that this latitude is an "unintended consequence" of the business judgment rule.

${ }^{197}$ GE's Jack Welch was forced to give up \$2.5 million per year in retirement benefits of exactly this kind—use of an \$11 million company apartment in NY for life, maid service, weekly fresh flowers and wine delivery, dry cleaning - when the benefits were disclosed by his second wife in a contested divorce proceeding. SeeMatt Murray, Rachel Emma Silverman \& Carol Hymowitz, GE's Jack Welch Meets Match in Divorce Court, WALL ST. J. (Nov. 27, 2002), available at http://www.wsj.com/articles/SB1038347809827912908.

${ }^{198}$ See, e.g., Bainbridge, supra note 146.
} 
instantiated in the U.S. over the last three decades has itself masked self-interest and created new agency problems. Regarding self-interest, as Lynne Dallas argued over a decade ago, “[a] 'new' managerialism has arisen that consists of short-term decision making and window dressing to impress the stock market at the expense of improving underlying corporation value.”199 In particular the shift to stock option compensation "provides unique opportunities for managerial self-dealing. . . . ${ }^{200}$ By 2015, the tight coupling of managers and markets has allowed managerial rent extraction in the U.S. to an historically unprecedented degree. ${ }^{201}$

With respect to accountability, we are back to the question of accountability to whom or what, and here the Delaware precedents provide a clear answer: accountability must be to the corporation and its shareholders, taking a long-term perspective on corporate well-being. Yet today's concern is that shareholders are putting short-term pressure on companies in ways that are unproductive for the future success of the corporate enterprise. ${ }^{202}$ Activist investors exert a significant part of this pressure, and an empirical debate is raging over their economic influence. ${ }^{203}$ But in terms of their influence on corporate decisions, Bill Bratton and Michael Wachter show that activist investors seek one of four things: that more money be given back to shareholders, in the form of share buy-backs or special dividends; that the company sell itself or

\footnotetext{
${ }^{199}$ Dallas, supra note 193, at 1363.

${ }^{200}$ Id. at 1377.

201 Both Chrystia Freeland and Thomas Piketty provide statistics on this point, and both identify executive compensation systems in the U.S. as contributing significantly to rapidly increasing economic inequality in the U.S. Chrystia FreEland, Plutocrats: The Rise of the New Global SuPER-Rich AND the FALl OF EVERYONE ELSE 211-222 (2012); THOMAS PIKETTY, CAPITAL IN THE TWENTY-FIRST CENTURY 294-303; 330-335; 505-515 (2014).

${ }^{202}$ See Jesse M. Fried, The Uneasy Case for Favoring Long Term Shareholders, 124 YALE L. J. 1554 (2015)(arguing that companies that repurchase or sell large volumes of their own shares can manipulate the stock prices, which undermines (in the case of repurchases) putting corporate money to more productive use).

${ }^{203}$ See John C. Coffee, Jr. \& Darius Palia, The Impact of Hedge Fund Activism: Evidence and Implications, Columbia University Law and Economics Working Paper No. 489, available at. http://papers.ssrn.com/sol3/papers.cfm?abstract_id=2496518 (finding evidence on most important questions regarding hedge fund activism ambiguous).
} 
its premium assets; that the company increase leverage, or that the company cut costs. ${ }^{204}$ Some of the actions to cut costs might be productive, such as finding ways to save energy or use fewer physical inputs. Others destroy longer-term value, such as putting off needed maintenance of plant and equipment, delaying marketing campaigns, cutting back on research and development, ${ }^{205}$ or even engaging in financial reporting fraud or value-destroying mergers and acquisitions, a concern identified by none other than Michael Jensen. ${ }^{206}$

In 2014, S\&P 500 companies spent 95\% of their earnings on share buybacks and dividends, and they look set to spend over $100 \%$ in $2015 .{ }^{207}$ This level of share buybacks is so high that Larry Fink, head of the world's largest asset manager, Blackrock, has written to all of the CEOs in the S\&P 500, expressing concerns that corporate leaders are meeting activists’ short-term pressures while "underinvesting in innovation, skilled workforces or essential capital expenditures necessary to sustain long-term growth.”208 One can argue that giving money back to shareholders is exactly what companies should be doing if they have no positive net present value investments to make. But it is bizarre to think that American companies, with their incredible confidence, creativity and organizational capacity, cannot find better, more productive uses of all of their earnings than giving them back to shareholders (with the not incidental benefit of keeping stock prices high and fueling a stock market rally), ${ }^{209}$ particularly in light of the enormous technical challenges facing the world from climate change, which scientists tell us

\footnotetext{
${ }^{204}$ See William B. Bratton \& Michael Wachter, supra note 127, at 508, 513. See generally William B. Bratton \& Michael Wachter, The Case Against Shareholder Empowerment, 158 U. PENN. L. REv. 653 (2010).

${ }^{205}$ See J.R. Graham, C.R. Harvey \& S. Rajgopal, The Economic Implications of Corporate Financial Reporting, 40:1 J. of Accounting and Economics (Dec. 2005).

${ }^{206}$ See Michael Jensen, The Agency Costs of Overvalued Equity, 34:1 FinAN. MNGMT. 5-19 (2005).

${ }^{207}$ See Edward Luce, US Share Buybacks Loot the Future, FinAN. TIMES (April 26, 2015), available at http://www.ft.com/intl/cms/s/0/1aaac576-e9bb-11e4-a687-00144feab7de.html\#axzz3ZJldjIW1.

${ }^{208}$ Id. quoting Larry Fink.

${ }^{209}$ See Lu Wang \& Callie Bost, S\&P Companies Spend Almost All Profits on Buybacks, Bloomberg (Oct. 6, 2014) (stating that "buybacks have helped fuel one of the strongest rallies of the past 50 years as stocks with the most repurchases gained more than 300 percent since March 2009”).
} 
requires a rapid transition to a low-carbon economy. A more productive system would

encourage managers and directors to manage their companies well and fairly for the longer-term, which will benefit tomorrow's shareholders in addition to today's, but which will also give management greater latitude to pursue the positive implications of fair employment policies, high-quality research and product development, good relationships with suppliers, and careful approaches to natural capital. In stylized form, that is what we see in stakeholder economies such as Scandinavia, the Netherlands, France, Germany or Austria, albeit under pressure, and that is what three-quarters of senior executives globally say they would want to see for their companies. $^{210}$

\section{Corporate Responsibility Reconciliation}

This chapter will conclude by trying to reconcile competing views of corporate responsibility as simultaneously too strong and too weak, assuming differing views of managers' and directors’ obligations from shareholder and stakeholder perspectives, but rejecting the view that corporate responsibility is somehow inconsistent with boards' fiduciary duties even in a shareholder system. Even Friedman believed that business has an obligation to conform "to the basic rules of the society, both those embodied in law and those embodied in ethical custom." ${ }^{\text {211 }}$ Economic theory recognizes negative externalities as one type of market failure justifying regulation. Each of the shareholder partisans quoted above thought that policies to address serious social problems should be developed through laws passed by democratic political processes, not by decisions of

\footnotetext{
${ }^{210}$ See Jonathan Bailey and Jonathan Godsall, Short-Termism: Insights from Business Leaders, McKinsey \& Company and CPPIB (Canadian Pension Plan Investment Board), Dec. 26, 2013 (findings from a global survey of 1,038 C-suite executives or board members, indicating that 79 percent felt pressure to deliver financial results in 2 years or less, even though 73 percent thought a reasonable strategic planning horizon should be at least 3 years). McKinsey and CPPIB are co-founders of Focusing Capital on the Long Term, which is described as "a collaborative initiative that is developing practical tools and approaches to help institutional investors and corporate directors enhance long-term value creation. See www.FCLT.org.

${ }^{211}$ See Friedman, supra note 138 , at 6.
} 
private companies' boards of directors. ${ }^{212}$ Looking at the self-regulatory initiatives that businesses have participated in can be used as a framework to determine which issues are broadly seen to demand regulatory solutions. At least in theory, the need for more hard law regulating social responsibility issues should be a point of agreement between those who consider corporate responsibility too strong when devolved to corporate boards for decision, and those who consider it too weak because it is voluntary and predominantly process based by emphasizing disclosure.

As both DeShutter and Wouters and Chanet argue, there is a range of regulatory approaches that can be used to produce a facilitative framework that permits voluntary initiatives to be more effective. In today's world, creative regulatory and voluntary approaches to the negative externalities of human rights abuses, labor exploitation, climate change and declining natural resources (including, most critically, water) are both hypothesized and in place in some parts of the world, but in need of serious scaling up to meet the full scope of global challenges. These approaches can be canvassed for best practices and further learning. Moreover, the accounting industry has developed and is continuing to develop approaches to integrated financial and nonfinancial reporting, and true-value accounting to incorporate the cost of negative externalities. ${ }^{213}$ Implementing intellectually-justified integrated reporting and accounting systems could go a long way towards providing the information and prices necessary to support capital and products markets that actually work the way market theories suggest they should work, including fully internalizing in the prices of products the social costs of producing and using those products. Beyond such strategies, the voluntary initiatives that companies have adopted to date in just

\footnotetext{
${ }^{212}$ See, e.g., Friedman, supra note 138; Fishel and Engel, supra note 145.

${ }^{213}$ See, for instance, KPMG International, A New Vision of Value: Connecting corporate and societal value creation (2014), available at http://www.kpmg.com/global/en/issuesandinsights/articlespublications/pressreleases/pages/corporate-societal-value-creation.aspx; INTEGRATED REPORTING <IR>, http://www.theiirc.org/.
} 
about every industry provide important information about what companies consider feasible. They also provide sources of empirical data about the effects of voluntary initiatives as a way to evaluate what more is needed to address particular social and environmental issues in each industry. If additional substantive regulation is needed to advance sustainability goals, Scandinavian legal and corporate governance approaches may be the most logical place to start to find models that work, at least as a good first approximation.

\section{CONCLUSION}

In conclusion, this author will offer the following anecdote. At a conference in Berlin on corporate responsibility four years ago, funded by the German government and held with some fair degree of pomp and circumstance in the German Parliament Offices Building, Dirk Matten, a leading management academic, described the importance of corporate responsibility with the following analogy. Having been told once by Jeremy Moon that of all the things that do not cure a cold, whiskey is the nicest, Matten said that his thinking on corporate responsibility is similar: that of all the things that won't cure contemporary capitalism, corporate responsibility is the nicest. At the least, in his view, it doesn't make the problems worse.

This chapter concludes by agreeing with Matten's assessment, with one important caveat. Corporate responsibility initiatives have likely improved the conditions of employment for at least hundreds of thousands of people around the world who would otherwise be subject to the mandates of unrestrained globalization. It certainly brings more attention to the environmental problems and opportunities of many productive processes and industries, and has thus motivated companies to develop innovative products and solutions to address those problems. It gives latitude to people who want to be change agents within organizations, and promotes deeper 
thinking among people and teams in organizations about the effects of the investments, products, services and relationships they are developing. As the empirical evidence is starting to show, it can even be a smart business strategy.

Corporate responsibility does not fundamentally change underlying power relationships between companies and citizens, however, since companies are volunteering to act to address social and environmental problems_or not. It might dissuade governments from regulating, though, and in that sense is making problems worse. It leaves gaping holes, such as its failure to establish "no go" zones. We will no doubt see "responsible tar sands mining” before the decade is out, which would be an intellectually-bankrupt concept and a tragic development for the stability of the climate. And as economic development proceeds apace throughout the world, improving millions of peoples' standard of living, there are still billions of people living on the equivalent of $\$ 2$ dollars a day or less. While those billions of people may surely benefit from greater access to productive enterprise, the underlying normative and material conditions of that access matter greatly. So, to the extent that we actually want to solve any of the underlying global problems of modern capitalism, stronger medicines than the pleasant whiskey of corporate responsibility are required. 